\title{
Influence of different sources of coal gangue used as aluminosilicate powder on the mechanical properties and microstructure of alkali-activated cement
}

\author{
B. J. Frasson, R.C.A. Pinto, J.C. Rocha $₫$ \\ Civil Engineering Department, ValoRes Waste Materials and Development of Sustainable Materials Laboratory, \\ Federal University of Santa Catarina, Florianópolis (Brazil) \\ \janaide.rocha@ufsc.br \\ Received 23 November 2018 \\ Accepted 28 March 2019 \\ Available on line 20 September 2019
}

\begin{abstract}
Coal mining wastes are associated with serious environmental problems; they have potential as building materials, including alkali-activated cement. In this study, the effect of different coal mining wastes on the mechanical properties and microstructural development of alkali-activated materials (AAMs) was evaluated through XRD, SEM and FTIR spectroscopy. Different alkali-activated compounds were produced; the alkaline solution was composed of $\mathrm{NaOH}+\mathrm{Na}_{2} \mathrm{SiO}_{3}$. The results obtained using the calcined coal sludge showed excellent mechanical performance, with compressive strength higher than $60 \mathrm{MPa}$. However, addition of metakaolin and ordinary Portland cement was necessary to increase the mechanical performance of calcined coal gangue materials. The formation of N-A-S-H gel and the incorporation of iron ions into the cementitious matrix were evidenced. Ultrasonic pulse velocity indicated the early polymerization during the reaction processes. The study verified that the different characteristics of the wastes influence the performance of alkali-activated materials.
\end{abstract}

KEYWORDS: Alkali-activated cement; Cement paste; Microstructure; Mechanical properties; Physical properties

Citation/Citar como: Frasson, B.J.; Pinto, R.C.A.; Rocha, J.C. (2019) Influence of different sources of coal gangue used as aluminosilicate powder on the mechanical properties and microstructure of alkali-activated cement. Mater. Construcc. 69 [336], e199 https://doi.org/10.3989/mc.2019.12618

RESUMEN: Estudio de la influencia de los diferentes residuos de carbón como aluminosilicatos en las propiedades mecánicas y la microestructura de los cementos activados alcalinamente. Los residuos de minería de carbón causan serios problemas ambientales, no obstante, tienen potencial como material de construcción, destacándose los cementos activados alcalinamente. El efecto de los residuos de carbón sobre las propiedades mecánicas y el desarrollo microestructural de los cementos activados alcalinamente son objeto de este estudio. Para ello, se utilizaron las técnicas de DRX, SEM y FTIR. Se produjeron diferentes compuestos activados alcalinamente, utilizando $\mathrm{NaOH}+\mathrm{Na}_{2} \mathrm{SiO}_{3}$ como activador alcalino y curado térmico $\left(50{ }^{\circ} \mathrm{C}\right.$ durante $\left.24 \mathrm{~h}\right)$. Los resultados obtenidos a partir del lodo de carbón calcinado mostraron un excelente rendimiento mecánico, con una resistencia a la compresión superior a $60 \mathrm{MPa}$. Sin embargo, en el caso de los materiales obtenidos a partir de la ganga de carbón calcinada, fue necesaria la adición de metacaolín y cemento Portland para aumentar sus resistencias mecánicas. Asimismo, se evidenció la formación de gel N-A-S-H y la incorporación de iones de hierro en la matriz cementante. El ensayo de velocidad de pulso ultrasónica indicó la polimerización inicial durante el proceso de reacción. Gracias a este se ha comprobado que las diferentes características de los residuos influyen en las propiedades y comportamiento de los correspondientes materiales activados alcalinamente.

PALABRAS CLAVE: Cemento activado alcalinamente; Pasta de cemento; Microestructura; Propiedades mecânicas; Propiedades físicas.

ORCID ID: B. J. Frasson (https://orcid.org/0000-0002-1074-0518); R.C.A. Pinto (https://orcid.org/0000-0002-0479-080X); J.C. Rocha (https://orcid.org/0000-0003-1074-3230)

Copyright: (C) 2019 CSIC. This is an open-access article distributed under the terms of the Creative Commons Attribution 4.0 International (CC BY 4.0) License. 


\section{INTRODUCTION}

Coal is a widely used fossil fuel, being responsible for around $40 \%$ of the world energy production. China, India and the United States are the largest coal producers (1). Coal is composed of hydrocarbons, derived from the decomposition of organic matter over millions of years. The mineral is interspersed with layers of rocks of different types including sandstone, shale and siltstone (2). The coal washing process results in coal gangue, a solid waste that is generally discharged into large deposition areas, leading to environmental problems, such as acid mine drainage (AMD) (3-4) and spontaneous combustion (5).

Coal gangue is a heterogeneous material and its physicochemical and mineralogical characteristics are dependent on the geology of the extraction field. It is comprised of a varied mixture of mineralogical components, such as quartz, kaolinite, illite, pyrite and others. The main chemical compounds are $\mathrm{SiO}_{2}$ and $\mathrm{Al}_{2} \mathrm{O}_{3}$, with traces of $\mathrm{Fe}, \mathrm{S}, \mathrm{Ca}$ and $\mathrm{Mn}(6-8)$. Some aluminosilicates are also present in the mineral phases, with little or no reactivity, and pre-treatment processes can promote more amorphous phase formation and less crystalline products $(6,9)$. These characteristics can enhance the potential for coal gangue to be used in the production of construction materials.

Studies on coal mining by-products have been conducted with materials from different origins, such as landfills (10-12), collected directly from washing plants (13) or coal sludge wastes $(10,14)$. The main focus of studies on coal wastes has been their potential for use as pozzolanic supplementary materials $(7,10,12,14,15)$, aggregate materials (11) or as a raw material for the production of bricks (16-17). These possible applications would reduce the large-scale production of solid wastes and, as a consequence, less land area would be needed for the final disposal of coal wastes.

Recently, several investigations have been conducted on the use of coal gangue as raw material in alkali-activated cement. Researchers have noted that it is necessary to include a secondary material, either to increase the calcium content of the alkaline medium (18) or to increase the aluminum content (19). A combination of $\mathrm{NaOH}$ and $\mathrm{Na}_{2} \mathrm{SiO}_{3}$, or addition of $\mathrm{Ca}(\mathrm{OH})_{2}$ can provide an alkaline medium for coal gangue alkali-activated cement $(9,20)$. Cheng et al. (9) ensured early strength by using Portland cement as a source of $\mathrm{CaO}$.

Alkali-activated binders are generally composed of aluminosilicate powders, obtained mainly from industrial by-products, such as fly ash (FA), ground granulated blast furnace slag (GGBFS), and alkaline solutions (21). Alkali-activated materials (AAMs) usually need thermal curing to improve the dissolution of reactive species (22). Soluble silicates are used to improve the dissolution process of powder materials, since the silica present is ready to react. Alkaline solutions can be prepared by adjusting the silica modulus (Ms), dissolving solid $\mathrm{NaOH}$ directly in the silicate solution (23-25). Depending on the Al-Si mineral dissolution, it may be necessary to optimize the concentration of the alkaline solution, which will affect the final properties of the alkaliactivated binder. Moreover, the addition of other materials from a secondary source, such as metakaolin or Portland cement, may be used to increase the $\mathrm{Al}$ and $\mathrm{Si}$ content, and when Portland cement is added to aluminosilicate these are referred to as hybrid systems (21).

It has been reported that low calcium $(<10 \% \mathrm{Ca})$ alkali-activated cement presents excellent mechanical properties $(23,26,27)$, sulfate attack resistance (28-31) and high durability (32). However, its microstructural development, hardening and mechanical strength are related to the type of materials and dosages used (33-35).

The aim of this research was to assess the use of coal wastes from different sources as powders in alkali-activated binders. Several alkali-activated binders were produced: simple systems or binary systems with the addition of metakaolin (MK) or ordinary Portland cement (OPC). Their microstructural development and mechanical properties were evaluated. Also, hybrid mortars produced with coal gangue and OPC were studied in order to observe their physical and mechanical properties.

\section{MATERIALS AND METHODS}

\subsection{Materials}

Three coal wastes were obtained from a coal washing plant located in Santa Catarina (Brazil): one from a conveyor belt (coal gangue; $\mathrm{CG}$ ), one from the decantation basin (coal sludge; CS), and one from a landfill area (spontaneous combustion coal gangue; SPC).

The raw materials were dried at a temperature of $105^{\circ} \mathrm{C} \pm 5^{\circ} \mathrm{C}$ for $24 \mathrm{~h}$ and the ground in a ball mill. The SPC was milled for $360 \mathrm{~min}$ and the CG and CS for $30 \mathrm{~min}$. The different grinding times were necessary to ensure particles smaller than $75 \mu \mathrm{m}$ (determined by dried sieving). The CG and CS materials were calcined at $700^{\circ} \mathrm{C}$ for $1 \mathrm{~h}$ in a muffle furnace and after this process the samples were referred to as CGT and CST, respectively (the SPC was not calcined).

Ordinary Portland cement (OPC) (36) and metakaolin (MK) were used to obtain the cement alkaline samples. Kaolin was calcined at $800^{\circ} \mathrm{C}$ for $2 \mathrm{~h}$ to obtain metakaolin. Sodium hydroxide $(\mathrm{NaOH}-$ P.A. $97 \%)$ and sodium silicate $\left(\mathrm{Na}_{2} \mathrm{SiO}_{3}\right.$ - P.A. with $12.7 \% \mathrm{Na}_{2} \mathrm{O}, 30.4 \% \mathrm{SiO}_{2}$ and $57.0 \% \mathrm{H}_{2} \mathrm{O}$ in solution) were used in the preparation of the alkaline solution (AS). 
The chemical compositions were determined by $\mathrm{X}$-ray fluorescence (XRF) on a Shimadzu instrument (model 7000). As shown in Table 1, the wastes are rich in $\mathrm{Al}_{2} \mathrm{O}_{3}$ and $\mathrm{SiO}_{2}$, with $\mathrm{Si} / \mathrm{Al}$ ratios of 2.70, 1.60 and 1.90 for the SPC, CST and CGT, respectively. The loss on ignition (LOI) is associated with presence of carbon and organic material and after calcination the LOI values for CST and CGT were lower compared with SPC.

The particle size distributions of the materials were measured on a Microtac S3500 and the results are given in Figure 1. The $\mathrm{D}_{50}$ value was approximately $5.7 \mu \mathrm{m}$ for CST and MK, whereas for CGT and SPC it was $10 \mu \mathrm{m}$. The Blaine test determines the fineness of a material and the values obtained were highest for CST, followed by SPC and CGT.

TABLE 1. Chemical and physical characteristics of raw materials

\begin{tabular}{lcrrrr}
\hline Characteristics & \multicolumn{1}{c}{ SPC } & \multicolumn{1}{c}{ CST } & CGT & OPC & MK \\
\hline Chemical (\%) & & & & & \\
$\mathrm{SiO}_{2}$ & 56.81 & 59.95 & 55.91 & 17.24 & 53.67 \\
$\mathrm{Al}_{2} \mathrm{O}_{3}$ & 16.96 & 30.35 & 24.81 & - & 44.66 \\
$\mathrm{Fe}_{2} \mathrm{O}_{3}$ & 7.34 & 2.51 & 8.73 & 4.01 & 0.38 \\
$\mathrm{~K}_{2} \mathrm{O}$ & 4.64 & 2.53 & 2.02 & 1.13 & 0.13 \\
$\mathrm{TiO}_{2}$ & 0.871 & 1.47 & 1.17 & 0.32 & - \\
$\mathrm{CaO}$ & 0.566 & 0.67 & 0.28 & 68.73 & - \\
$\mathrm{SO}_{3}$ & - & 0.38 & 2.11 & 0.09 & - \\
$\mathrm{MnO}$ & 0.082 & 0.05 & 0.01 & 3.81 & - \\
$\mathrm{LOI}$ & 12.56 & 1.90 & 4.50 & 3.16 & 0.30 \\
$\mathrm{Blaine}(\mathrm{m} / \mathrm{kg})$ & 1208.79 & 1695.11 & 492.36 & 476.5 & 777.15 \\
$\mathrm{Si} / \mathrm{Al}(\mathrm{mol} / \mathrm{mol})$ & 2.70 & 1.60 & 1.90 & - & 1.00 \\
\hline
\end{tabular}

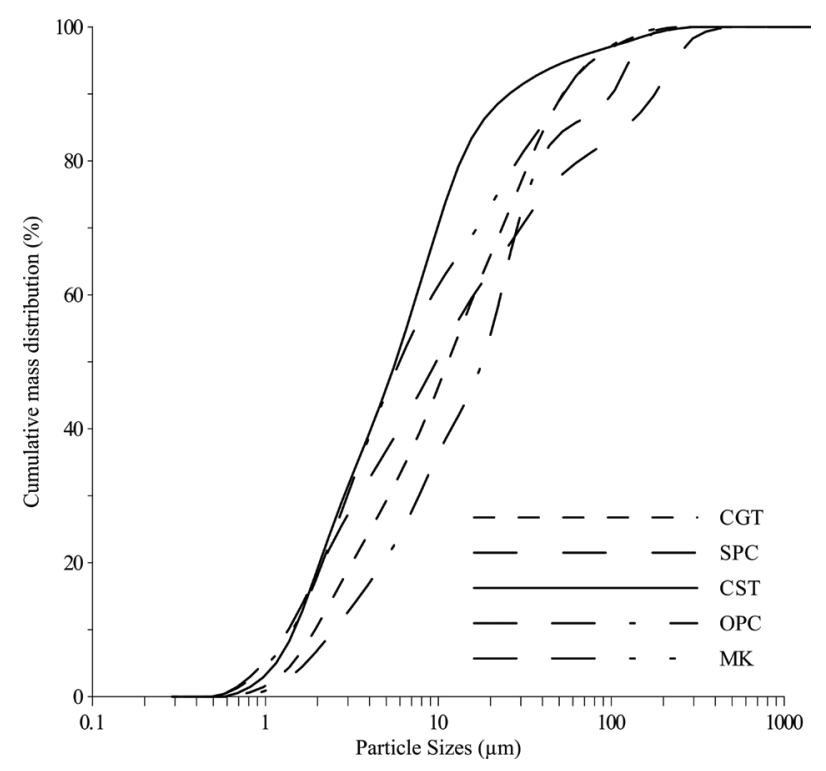

FIGURE 1. Particle size distribution of materials.
The mineralogical content was determined by X-ray diffraction (XRD) on a Phillips X-Pert 1 analyzer, with $\mathrm{Cu} \mathrm{Ka1}(\lambda=1.54056)$, a scan step of $0.02^{\circ}(1 \% \mathrm{~min})$ and $2 \theta$ angle of $3^{\circ}$ to $60^{\circ}$. The mineralogical composition in Figure 2 shows that the raw wastes were composed of quartz, muscovite and kaolinite, and after calcination the kaolinite peaks disappear due to dehydroxylation caused by thermal stress (14-15).

\subsection{Methods}

The compositions and molar ratios of the alkaliactivated materials (AAMs) are shown in Table 2. The alkaline solution (AS) was prepared by dissolving $\mathrm{NaOH}$ pellets in $\mathrm{Na}_{2} \mathrm{SiO}_{3}$ to achieve a silica modulus of $1.5\left(\mathrm{SiO}_{2} / \mathrm{Na}_{2} \mathrm{O}\right)$. No extra water was added. The dry powders were mixed and then, in a ratio of 1:1 (powders: AS), they were mixed with the AS for $5 \mathrm{~min}$. The AAMs were placed in a hermetically sealed cylindrical mold $(20 \mathrm{x} 40 \mathrm{~mm})$ and cured at $50^{\circ} \mathrm{C}$ for $24 \mathrm{~h}$. They were then demolded, sealed with PVC plastic and kept at room temperature until testing. A loss of workability was observed for all 25\%OPC pastes and thus a content of $38 \%$ of extra water was added to these mixes. Reference pastes were produced using MK and OPC. The former was mixed with AS and the latter was obtained with the same $\mathrm{H}_{2} \mathrm{O}$ /solids ratio (0.38) as the AAM systems.

The compressive strength test was performed on the samples at ages of 1,7 and 28 days, in an Instron 2245 testing machine, with a load cell of $50 \mathrm{kN}$ and velocity rate of $3 \mathrm{kN} / \mathrm{s}$. Six cylindrical micro-samples of AAM were tested at each age. The software provided the stress-strain curve, which allowed the elastic modulus to be obtained (37).

Microstructural analysis was performed on crushed cylindrical samples that were immersed in acetone for $24 \mathrm{~h}$, filtered and oven dried. Samples with $100 \%$ of coal wastes and $25 \%$ of OPC, after 1 and 28 days of curing, were selected. The objective of choosing systems with OPC was to evaluate the potential for $\mathrm{CaO}$ to improve the mechanical strength and alter the microstructure. However, the AAMs with MK showed a better mechanical performance.

The mineralogical content was determined by XRD on a Phillips X-Pert 1 analyzer, with $\mathrm{Cu} \mathrm{Ka1}$ $(\lambda=1.54056)$, a scan step of $0.02^{\circ}(1 \% \mathrm{~min})$ and $2 \theta$ angle of $3^{\circ}$ to $60^{\circ}$. Fourier transform infrared (FTIR) spectroscopy was performed on a JASCO FTIR 4200 instrument in transmission mode, using $\mathrm{KBr}$ pellets (1:60, powder: $\mathrm{KBr})$. Measurements were taken from $400 \mathrm{~cm}^{-1}$ to $4000 \mathrm{~cm}^{-1}$, with a resolution of $4 \mathrm{~cm}^{-1}$. Scanning electron microscopy (SEM) was performed on a JEOL JSM-6369 LV microscope and the samples were prepared by fragmentation and gold coating. 


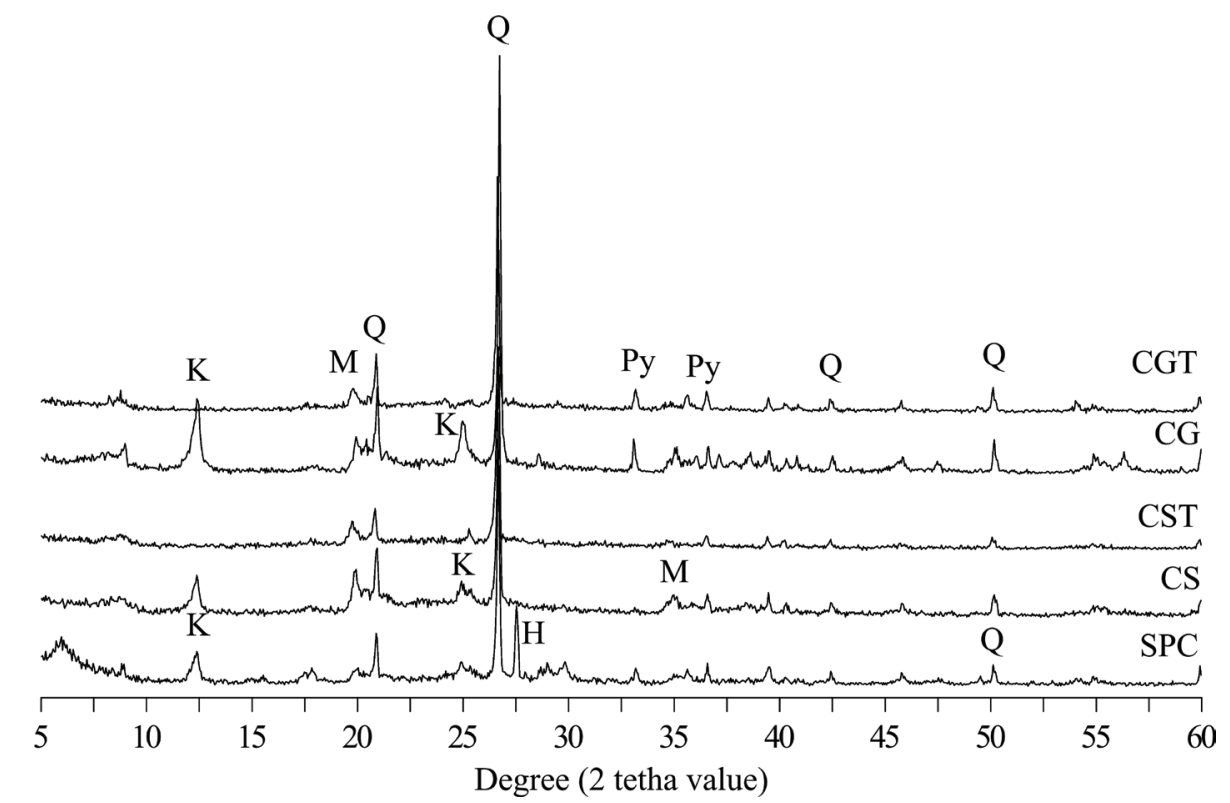

FIGURE 2. XRD patterns for the raw and calcined coal gangue materials. Q is quartz (PDF: 33-1161), K is kaolinite (PDF: 6-263), $\mathrm{M}$ is muscovite (PDF: 2-263), Py is pyrite (PDF: 42-1340) and $\mathrm{H}$ is hematite (PDF: 33-664).

TABLE 2. Dosages and molar ratios of coal mining waste-based alkali-activated material (AAM)

\begin{tabular}{|c|c|c|c|c|c|c|c|c|}
\hline Mix & Residue & Waste (g) & MK (g) & OPC (g) & Si/Al (mol/mol) & $\mathrm{Na} / \mathrm{Si}$ (mol/mol) & $\mathrm{Na} / \mathrm{Al}(\mathrm{mol} / \mathrm{mol})$ & $\mathrm{H}_{2} \mathrm{O} / \mathrm{Na}_{2} \mathrm{O}$ \\
\hline 100SPC & SPC & 100 & - & - & 4.22 & 0.43 & 1.83 & 9.89 \\
\hline 70SPC30MK & & 70 & 30 & - & 2.80 & 0.44 & 1.22 & 9.89 \\
\hline 50SPC50MK & & 50 & 50 & - & 2.28 & 0.44 & 1.01 & 9.89 \\
\hline 90SPC10OPC & & 90 & - & 10 & 4.48 & 0.45 & 2.05 & 9.89 \\
\hline 88SPC12OPC & & 88 & - & 12 & 4.05 & 0.49 & 1.98 & 9.89 \\
\hline 75SPC25OPC & & 75 & - & 25 & 4.99 & 0.49 & 2.44 & 16.48 \\
\hline $100 \mathrm{CST}$ & CST & 100 & - & - & 2.44 & 0.42 & 1.02 & 9.89 \\
\hline 70CST30MK & & 70 & 30 & - & 2.10 & 0.43 & 0.89 & 9.89 \\
\hline 50CST50MK & & 50 & 50 & - & 1.91 & 0.43 & 0.83 & 9.89 \\
\hline 90CST10OPC & & 90 & - & 10 & 2.59 & 0.44 & 1.13 & 9.89 \\
\hline 88CST12OPC & & 88 & - & 12 & 2.46 & 0.47 & 1.16 & 9.89 \\
\hline 75CST25OPC & & 75 & - & 25 & 2.87 & 0.47 & 1.36 & 16.48 \\
\hline 100CGT & CGT & 100 & - & - & 2.85 & 0.44 & 1.25 & 9.89 \\
\hline 70CGT30MK & & 70 & 30 & - & 2.28 & 0.44 & 1.01 & 9.89 \\
\hline 50CGT50MK & & 50 & 50 & - & 2.01 & 0.44 & 0.89 & 9.89 \\
\hline 90CGT10OPC & & 90 & - & 10 & 3.03 & 0.46 & 1.39 & 9.89 \\
\hline 88CGT12OPC & & 88 & - & 12 & 2.84 & 0.49 & 1.40 & 9.89 \\
\hline 75CGT25OPC & & 75 & - & 25 & 3.38 & 0.49 & 1.67 & 16.48 \\
\hline $100 \mathrm{MK}$ & - & - & 100 & - & 1.54 & 0.45 & 0.69 & 9.89 \\
\hline
\end{tabular}

$\mathrm{H}_{2} \mathrm{O} /$ solid $=0.38(\mathrm{~g} / \mathrm{g})$ and $\mathrm{NaOH} / \mathrm{Na}_{2} \mathrm{SiO}_{3}=0.0735(\mathrm{~g} / \mathrm{g})$.

To verify the degree of reactivity, one gram of AAM was immersed in $250 \mathrm{ml}$ of $\mathrm{HCl}$, with a ratio of $1: 20$ for $3 \mathrm{~h}$, filtered, dried at a temperature of $105^{\circ} \mathrm{C}$ and calcinated at $1000^{\circ} \mathrm{C}$ for $1 \mathrm{~h}$. The ratio between the residual and initial masses was then calculated, as proposed in the literature (38).
The pastes select to produce the mortars were 100CST, 75CST25OPC, 75CGT25OPC and $75 \mathrm{SPC} 25 \mathrm{OPC}$, the first due to its better mechanical properties and the others to observe the influence of the presence of $\mathrm{CaO}$ on the mortar samples. Standard sand was used $[2.5 / 0.15 \mathrm{~mm}](39)$, in a 
ratio of 1:3 (AAM:sand, by mass). The mortars were renamed as M100CST, M75CST, M75CGT and M75SPC, respectively. Polycarboxylate was added at content of $1 \%$, calculated by mass of the powder material.

The AS was added to the powder mixes. The mixtures were homogenized for $5 \mathrm{~min}$ and then cast in cylindrical steel molds $(5 \times 10 \mathrm{~cm})$ and protected with a plastic film. The curing process was the same as that described for the pastes.

The compressive strength was evaluated, at 28 days, using a SoloTest machine, with a stress rate of $0.5 \mathrm{MPa} / \mathrm{s}$. The ultrasonic pulse velocity (UPV) test was performed on a Pundit Lab ${ }^{\circledR}$ test instrument (model 6.0), with $200 \mathrm{kHz}$ frequency transducer, at ages of 7, 14, 21 and 28 days, as described in the literature (40). The dynamic elastic modulus (Ed) was calculated using Equation [1], with an assumed Poisson's ratio $(\mu)$ of 0.2 . The density ( $\rho)$ was obtained from the mass/volume ratio while UPV (v) was determined by testing.

$$
E_{d}=v^{2} \rho \frac{(1+\mu)(1-2 \mu)}{(1-\mu)}
$$

The capillary water absorption was evaluated, at 28 days, by selecting three samples of each mortar. Before the test, the samples were oven dried at $50^{\circ} \mathrm{C}$ for $72 \mathrm{~h}$. This test consists of measuring the variation in the amount of water in a Mariotte tube (41), which is related to the water absorbed by the sample.
The capillary water absorded amount is ploted as function of $\sqrt{t}$. By means of this test the sorptivity of the mortar can be calculated using Equation [2], where ' $\mathrm{Vt}$ ' is the total volume absorbed $\left(\mathrm{m}^{3}\right)$, ' $\mathrm{A}$ ' is specimen area $\left(\mathrm{m}^{2}\right)$, ' $\mathrm{S}$ ' is sorptivity $\left(\mathrm{m} . \mathrm{s}^{-\mathrm{I} / 2}\right)$, and ' $\mathrm{t}$ ' is time (h). After the capillary water absorption had been determined, the samples were dried at $50^{\circ} \mathrm{C}$ for $24 \mathrm{~h}$ the water absorption test was performed (42).

$$
\frac{V t}{A}=S \cdot \sqrt{ } t
$$

\section{RESULTS}

\subsection{Pastes: mechanical properties}

The compressive strength tests were performed at sample ages of 1,7 and 28 days and the results are shown in Figures 3, 4 and 5. The systems showed an increase in compressive strength, over the cure time. Better mechanical performance was observed for all CST-AAMs compared to CGT and SPC, which can be explained by differences in the chemical properties, fineness (particle size and Blaine results), and mineralogical content (the CST samples tend to have a greater amount of amorphous phase).

Values of $68.5 \mathrm{MPa}, 24.6 \mathrm{MPa}$ and $6.9 \mathrm{MPa}$ were obtained for 100CST, 100CGT and 100SPC, respectively, at the age of 28 days. The addition of MK leads to an increase in the mechanical strength in all cases, due mainly to the amorphous phase of MK. Figure 6 shows the results for the static

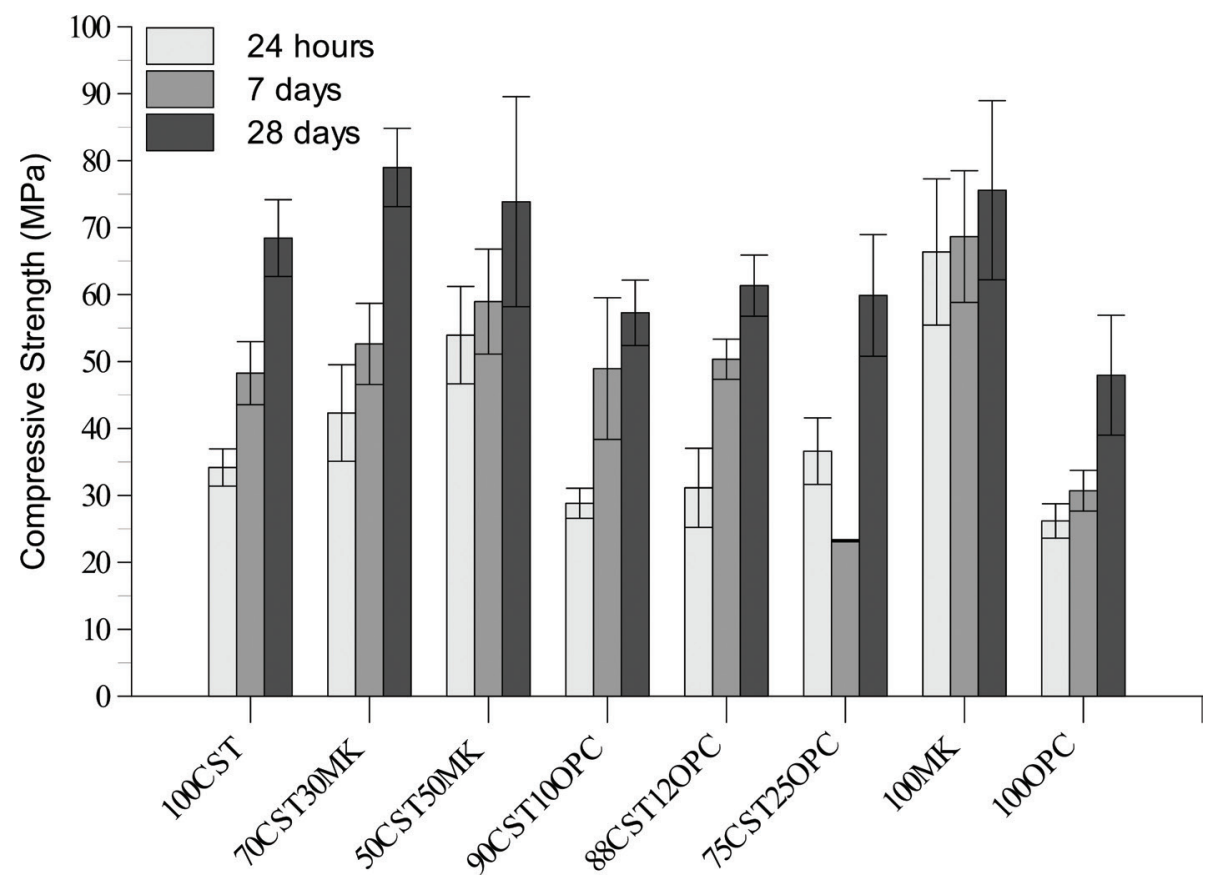

Figure 3. Compressive strength of CST-AAMs. 


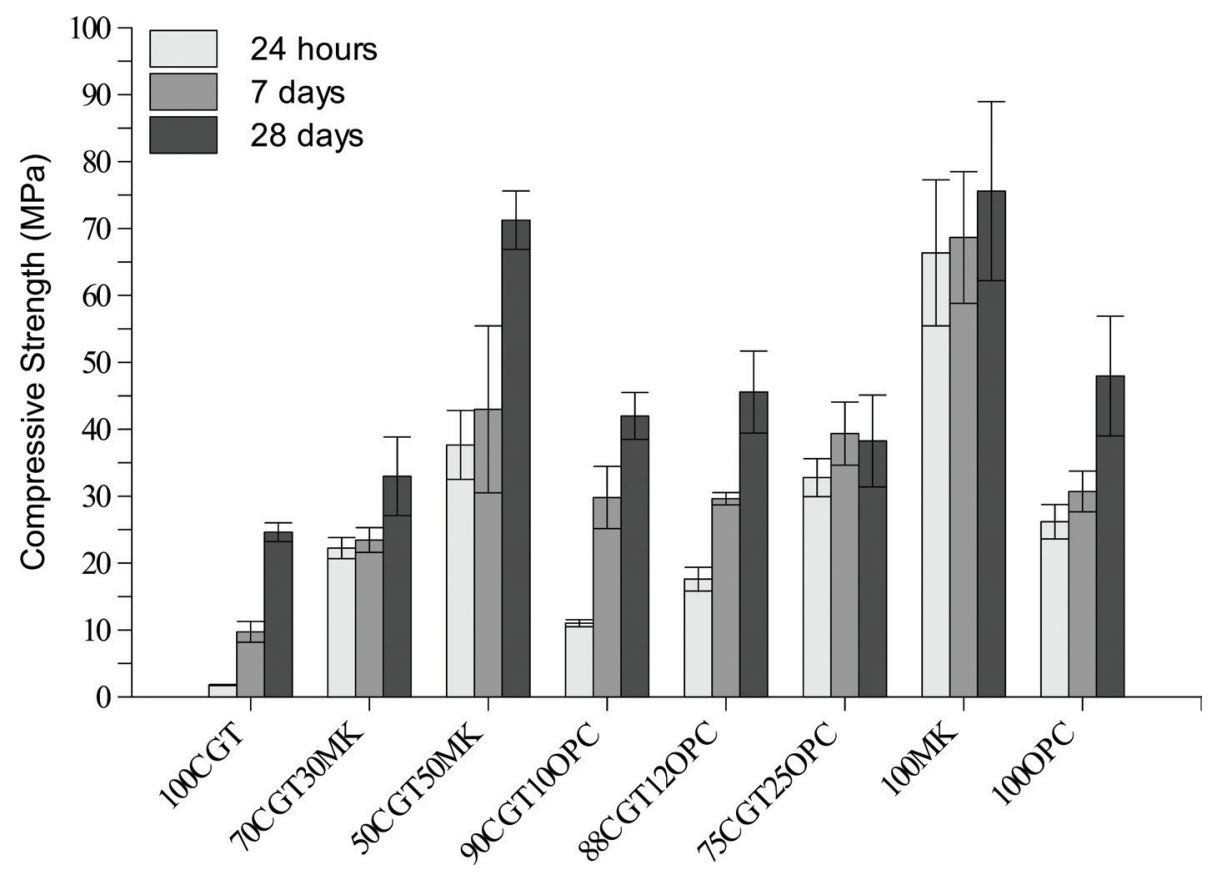

Figure 4. Compressive strength of CGT-AAMs.

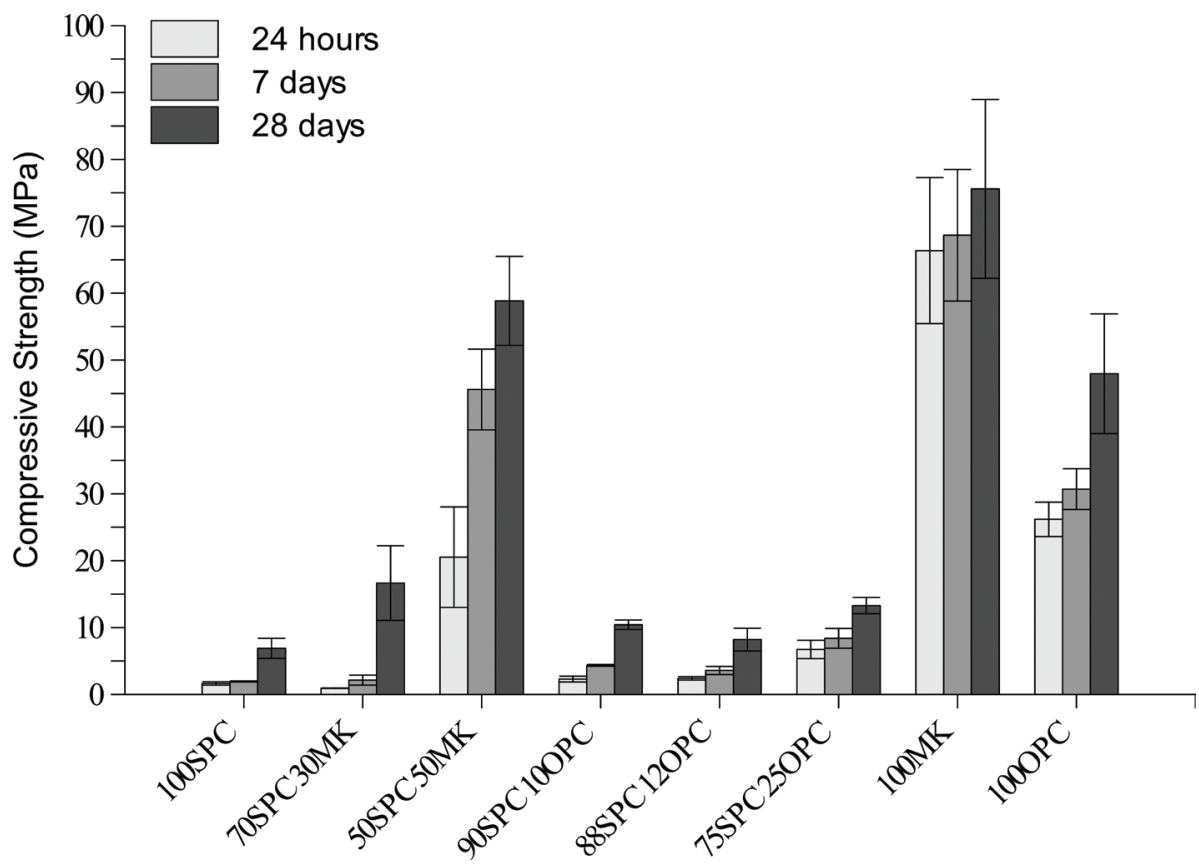

FIgURE 5. Compressive strength of SPC-AAMs.

elastic modulus calculated from the stress $\mathrm{x}$ strength data. It was found that the addition of metakaolin improved the mechanical strength and stiffness, in all cases, to a greater degree than the OPC.

At an early age, the additions improved the mechanical properties, mainly in the case of the
CGT cements. Mixtures of SPC-MK showed good mechanical performance only with MK contents of over $50 \%$. Metakaolin is a more reactive material, mainly due to its chemical (Si/Al content) and mineralogical (amorphous phases) characteristics (26), which can explain its excellent results. The addition 
(a)

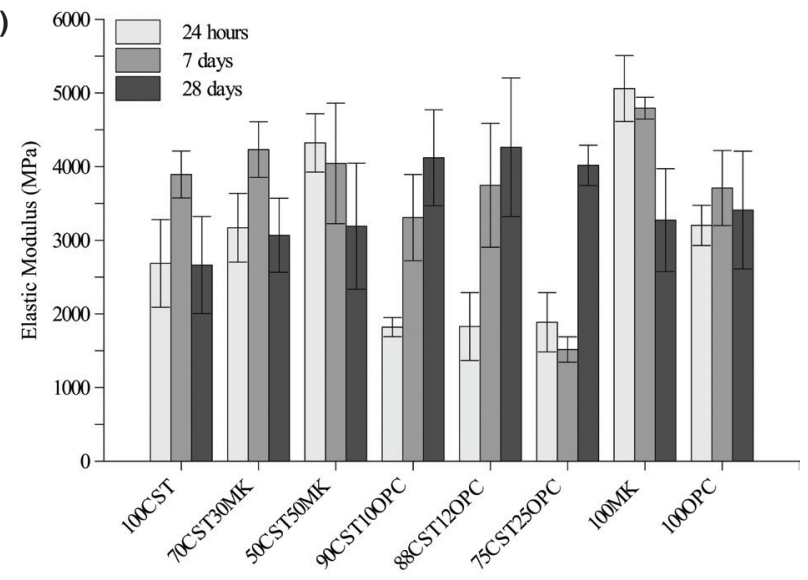

(b)

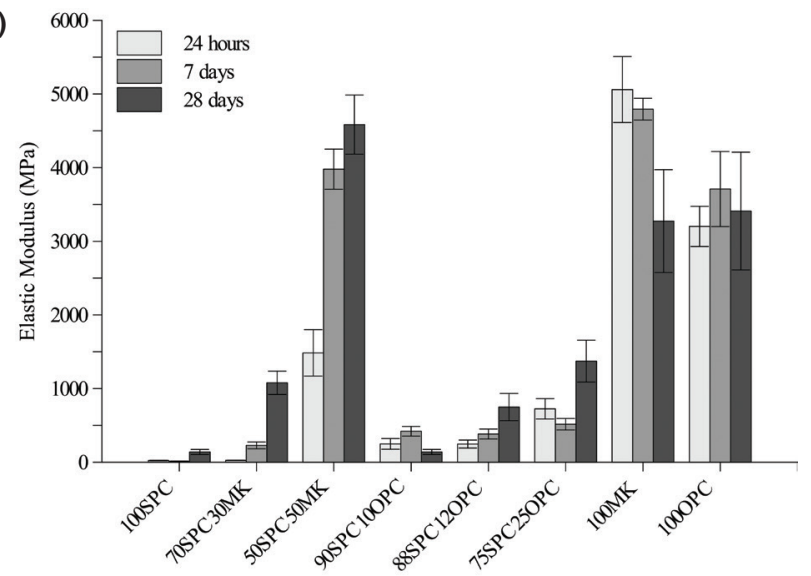

(c)

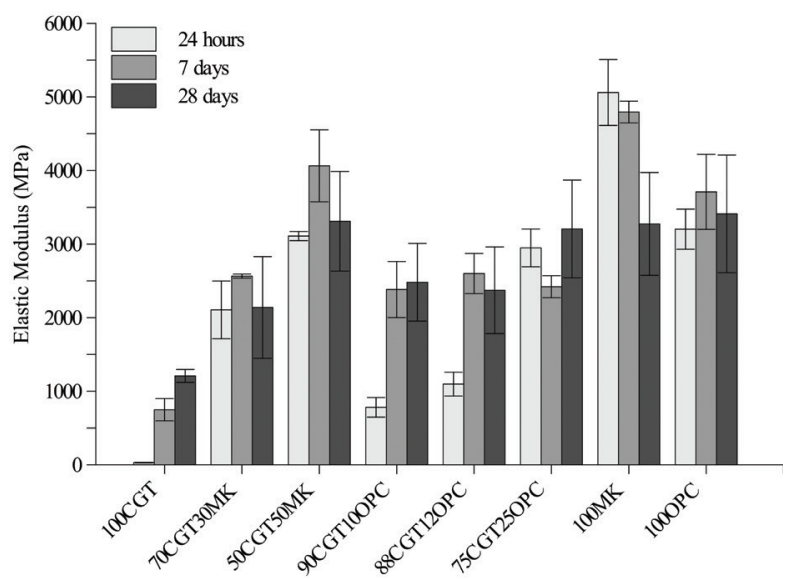

FIGURE 6. Elastic modulus of coal mining waste-based alkali-activated materials (a) CST; (b) SPC; and (c) CGT.

of calcium as OPC can improve the compressive strength (25), which is attributed to the microstructure formed.

Some mixtures were selected to perform reaction degree (RD) analysis and Figure 7 shows the results. The CST-AAMs present higher RDs, more than $60 \%$ for all cases and ages, which is similar to the value for $100 \mathrm{MK}$. In contrast, the SPC-AAMs provided lower values. The 100CGT RD value was also below $60 \%$, but showed an improvement when mixed with supplementary materials. These results could be related to the chemical, fineness and mineralogical properties of the materials, which may explain the mechanical properties of AAMs.

The main factors that may have influenced the mechanical results obtained for the pastes are: i) the chemical components of CST residues with a higher alumina content and $\mathrm{Si} / \mathrm{Al}$ ratio (1.60) than the other residue; ii) an increase in the particle finesses, since the values for the CST used in this study were more than $40 \%$ and $200 \%$ higher compared with the SPC and CGT, respectively; and, iii) the mineralogical composition, since XRD patterns for the coal sludge waste after calcination the kaolinite peaks had disappeared, suggestion the formation of semicrystalline phases. Also, it should be noted that the $\mathrm{Si} / \mathrm{Al}$ ratio (Table 2) may be related to the mechanical properties. Mixes with the lowest $\mathrm{Si} / \mathrm{Al}$ ratio reached a higher compressive strength, especially those comprised of CST with metakaolin addition.

\subsection{Pastes: microstructural analysis}

Microstructural analysis was performed on samples with waste only and with OPC replacement (to assess the influence of calcium on the microstructural development). Figures 8, 9 and 10 show the diffractograms for selected alkali-activated cement samples. After activation, the X-ray diffractogram exhibits a halo from $20^{\circ}$ to $35^{\circ}(2 \theta)$, suggesting the formation of sodium aluminosilicate gel (N-A-S-H) $(13,38,43)$. Peaks associated with crystalline phases, such as quartz, muscovita and pyrite (for CGTAAMs), are present. The addition of OPC displaces the halo to higher $2 \theta$ values since the calcium oxide modifies the structure of vitreous siliceous phases (44). The chemical and mineralogical properties of CST can influence the microstructural development 


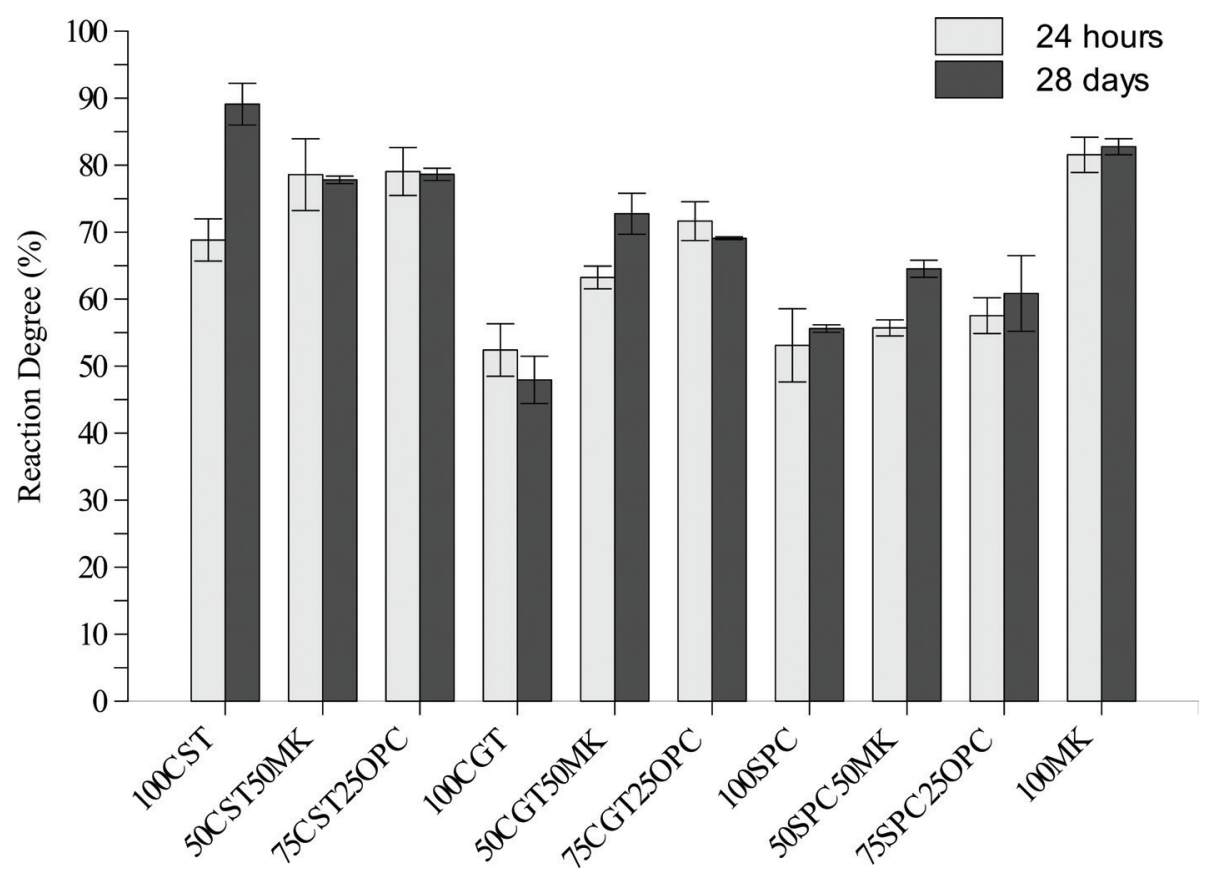

FIGURE 7. Reaction degree of coal mining waste-based alkali-activated materials.

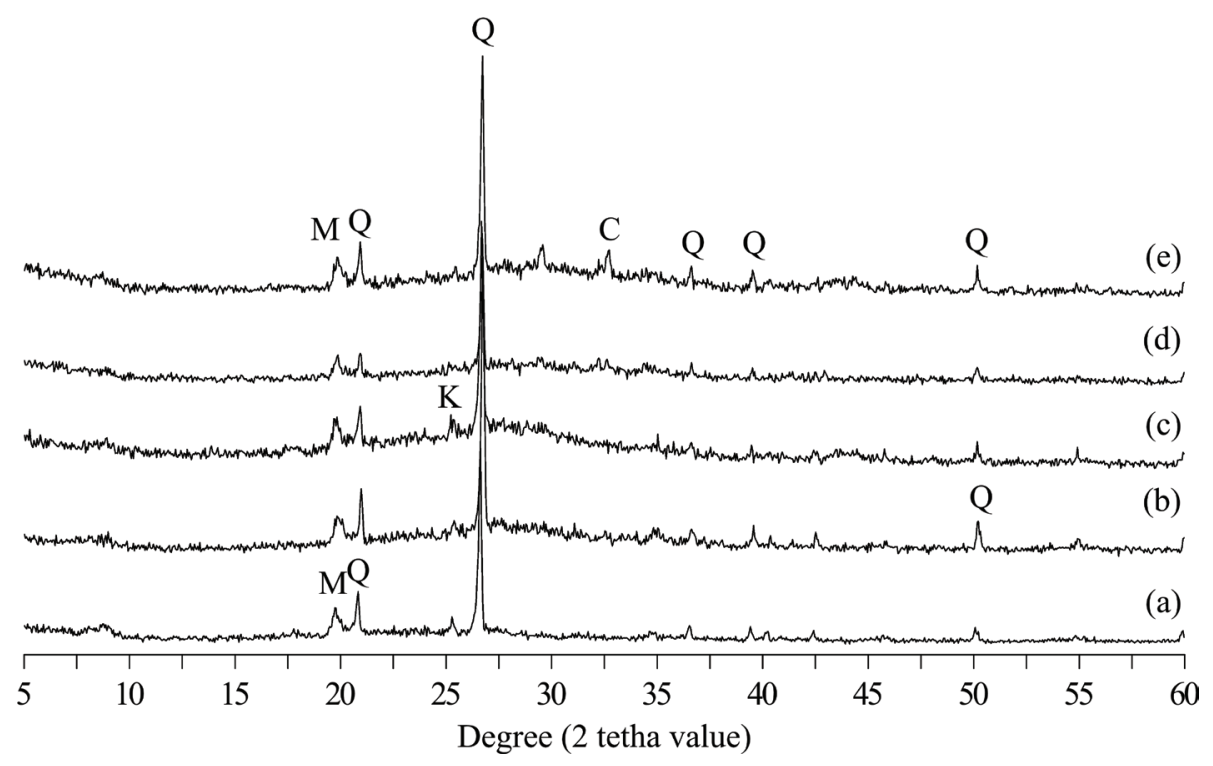

FIGURE 8. XRD patterns for CST-based alkali-activated cements. (a) CST; (b) 100CST (1 day); (c) 100CST (28 days); (d) 75CST25OPC (1 day); and (e) 75CST25OPC (28 days). Q is quartz (PDF: 33-1161), K is kaolinite (PDF: 6-263), $\mathrm{M}$ is muscovite (PDF: 2-263) and $\mathrm{C}$ is calcite (PDF: 5-586).

of AAMs and the amorphous phase is more clearly observed than in the case of CGT and SPC.

The FTIR transmission spectra are shown in Figures 11, 12 and 13. The presence of the broad band for $\mathrm{O}-\mathrm{H}$ asymmetric stretching $\left(3000-3700 \mathrm{~cm}^{-1}\right)$ and the $\mathrm{H}-\mathrm{O}-\mathrm{H}$ deformation band $\left(1600 \mathrm{~cm}^{-1}\right)$, indicate chemically-bound water, which is associated with the formation of hydrated compounds $(9,45)$. The broad band between $800 \mathrm{~cm}^{-1}$ and $1200 \mathrm{~cm}^{-1}$ is assigned to the asymmetric stretching vibration of $\mathrm{Si}-\mathrm{O}-\mathrm{T}$ ( $\mathrm{T}$ is $\mathrm{Al}$ or $\mathrm{Si})$. The main constituents in these materials are tetrahedral $\mathrm{SiO}_{4}$ and $\mathrm{AlO}_{4}$ in different structural orders (46). The initial waste presents the Si-O-T band close to $1030-1050 \mathrm{~cm}^{-1}$, but after 


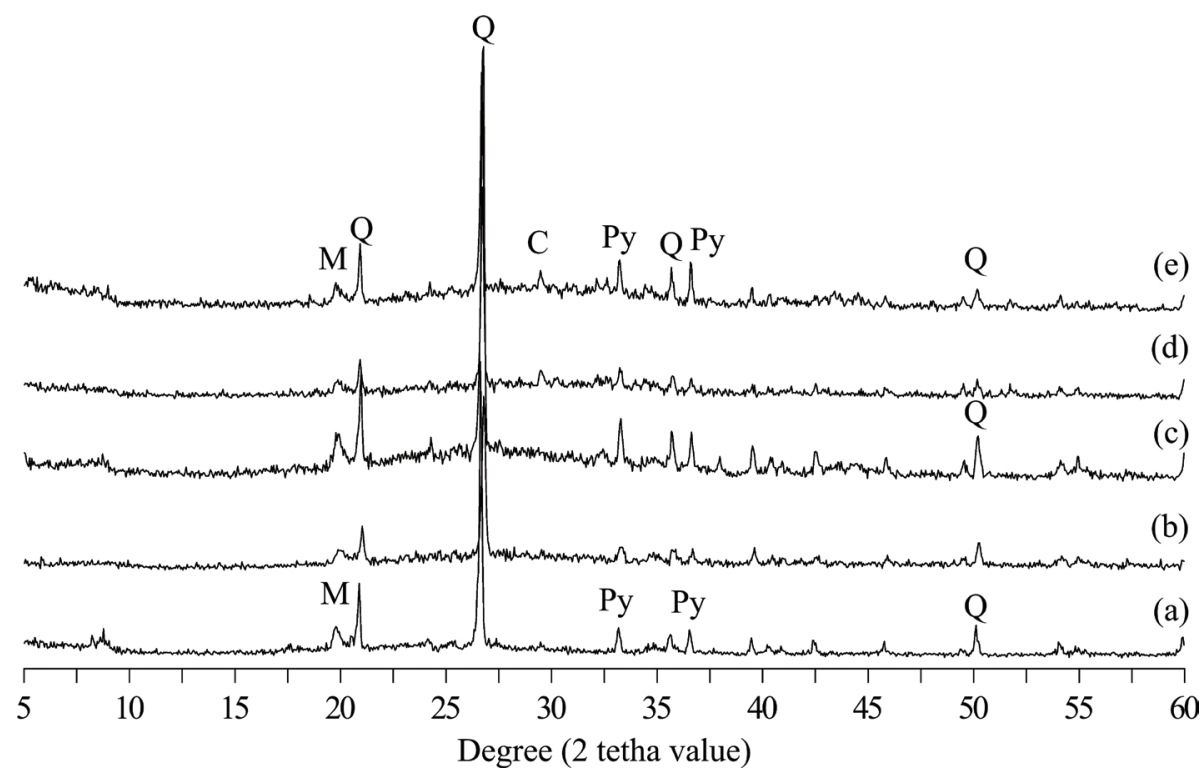

FIGURE 9. XRD patterns for CGT-based alkali-activated cements. (a) CGT; (b) 100CGT (1 day); (c) 100CGT (28 days); (d) 75CGT25OPC (1 day); and (e) 75CGT25OPC (28 days). Q is quartz (PDF: 33-1161), M is muscovite (PDF: 2-263), Py is pyrite (PDF: 42-1340) and C is calcite (PDF: 5-586).

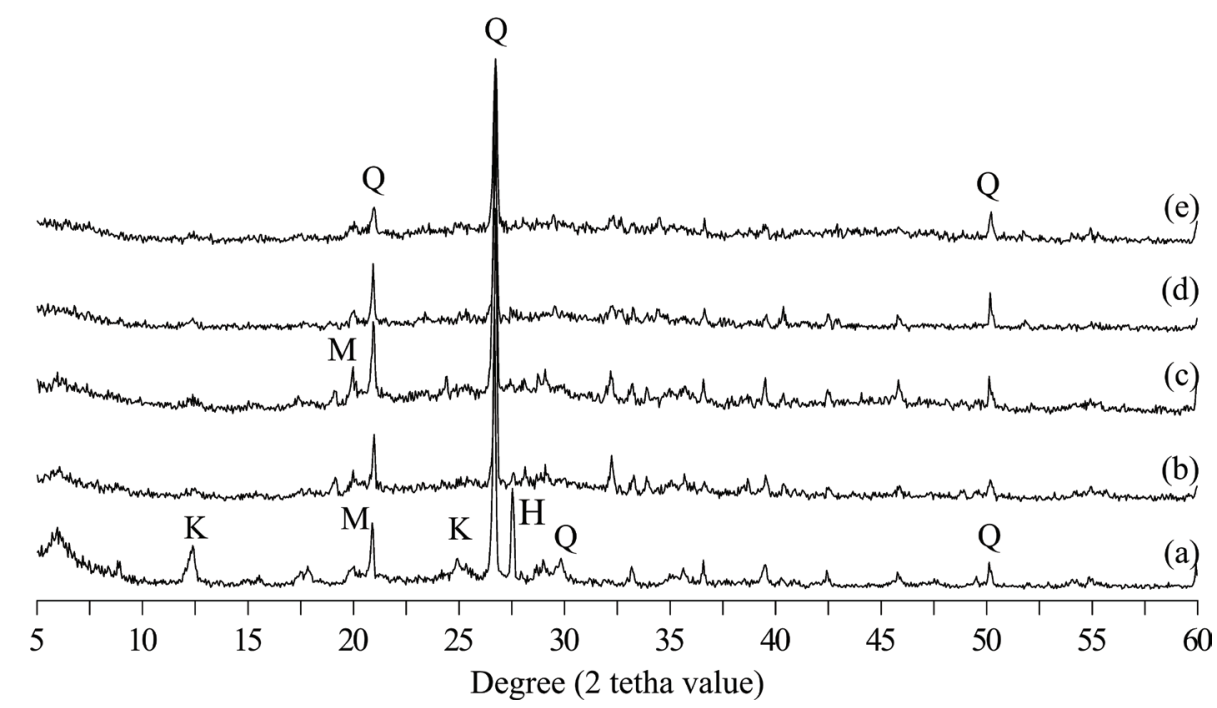

FIGURE 10. Reaction degree of coal mining waste-based alkali-activated materials. XRD patterns of SPC based alkali-activated cements (a) SPC; (b) 100SPC (1 day); (c) 100SPC (28 days); (d) 75SPC25OPC (1 day); and (e) 75SPC25OPC (28 days). Q is quartz (PDF: 33-1161), $\mathrm{K}$ is kaolinite (PDF: 6-263), M is muscovite (PDF: 2-263) and $\mathrm{H}$ is hematite (PDF: 33-664).

alkali activation this band is shifted to lower frequencies, which indicates the formation of gel-type aluminosilicates (45).

The bands at between $800-500 \mathrm{~cm}^{-1}$ are associated with the tetrahedral vibration of T-O. The interpretation of bands in this range can be difficult and the spectra show weak intensity for all samples. This range corresponds to secondary building units (SBU) and aluminosilicate systems $(45,46)$. The main bands are observed at $520-550 \mathrm{~cm}^{-1}$ and $760-780 \mathrm{~cm}^{-1}$, associated with octahedral aluminum and the stretching vibration of Si-O-T (9), respectively.

Frequencies between $470-450 \mathrm{~cm}^{-\mathrm{r}}$ are related to the bending vibration of $\mathrm{T}-\mathrm{O}$ and after alkaline activation the position of this band is almost the same and its intensity is similar to that on the spectra for 
(e)

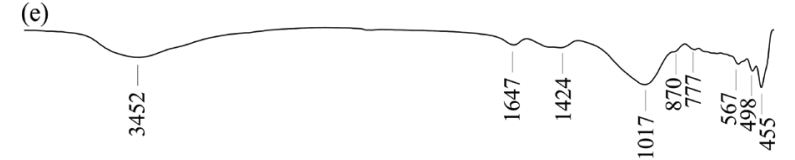

(d)

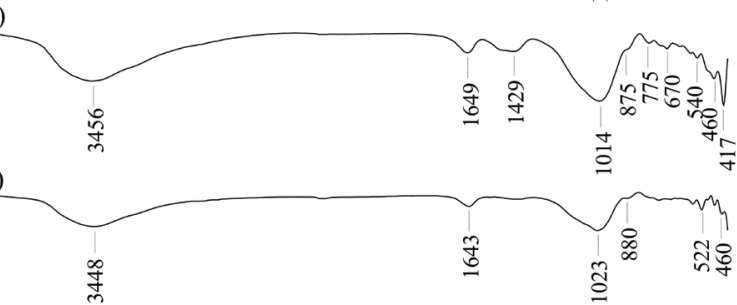

(b)

(a)

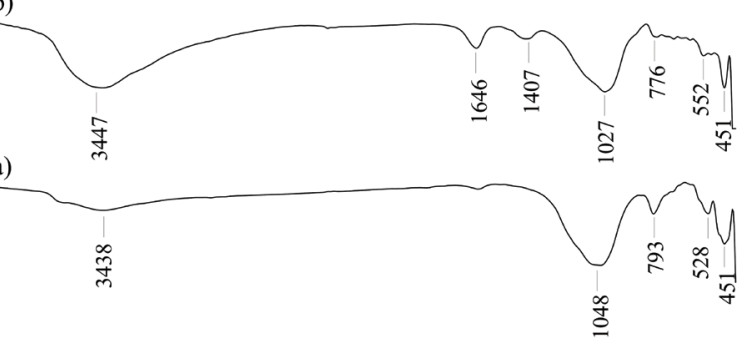

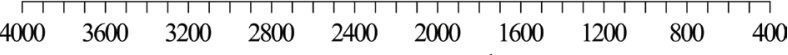

FIGURE 11. FTIR spectra for CST-based alkali-activated cements: (a) CST; (b) 100CST-1d; (c) 100CST-28d; (d) 75CST25OPC-1d; and (e) 75CST25OPC-28d.

(e)

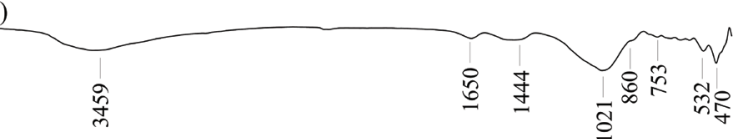

(d)

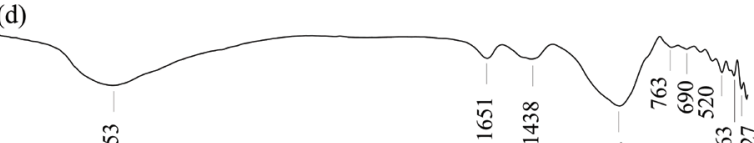

(c)

$\stackrel{n}{m}$
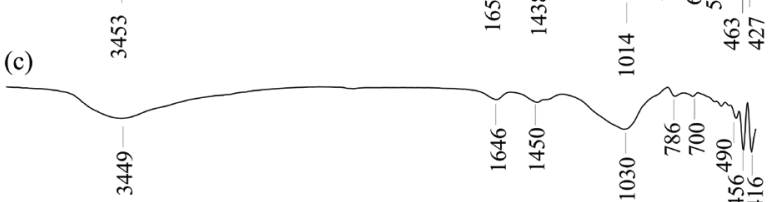

(b)
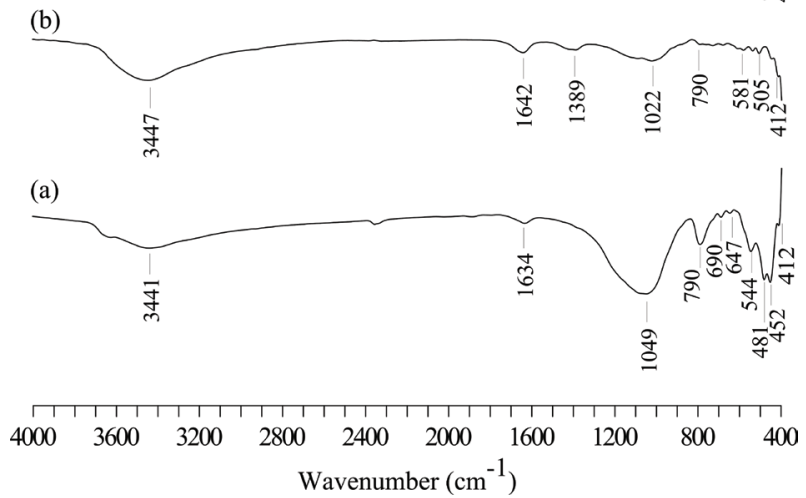

FIGURE 12. FTIR spectra for CGT-based alkali-activated cements: (a) CGT; (b) 100CGT-1d; (c) 100CGT-28d; (d) 75CGT25OPC-1d; and (e) 75CGT25OPC-28d. (e)

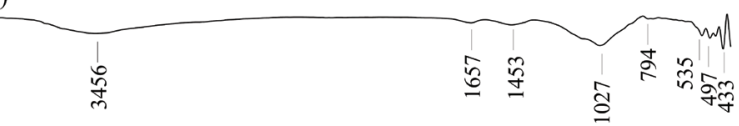

(d)

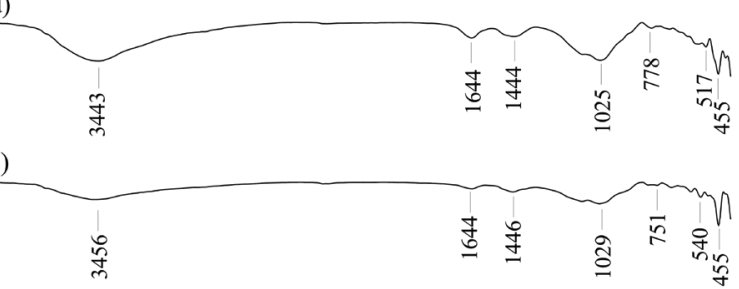

(b)

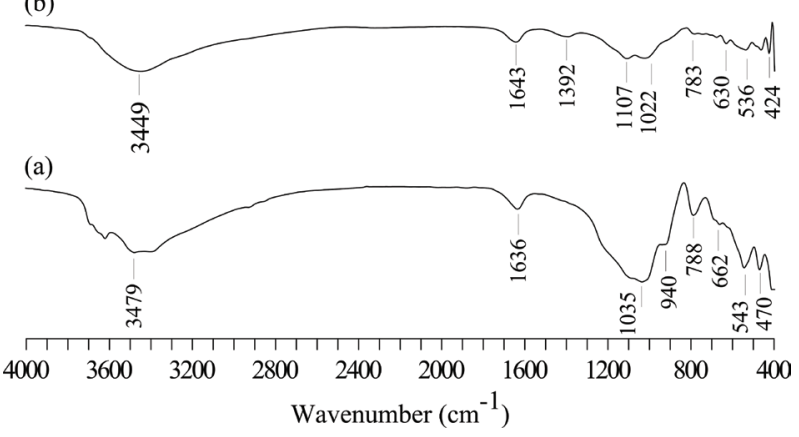

FIGURE 13. FTIR spectra for SPC-based alkali-activated cements: (a) SPC; (b) 100SPC -1d; (c) 100SPC -28d; (d) 75SPC25OPC-1d; and (e) 75SPC25OPC-28d.

the initial waste (46). Weak stretching vibrations of $\mathrm{N}-\mathrm{O}$ and O-C-O $\left(1450-1389 \mathrm{~cm}^{-1}\right)$ are present, which indicates traces of carbonates (47). Strong bands in the ranges of $1027-1014 \mathrm{~cm}^{-1}, 1030-1021 \mathrm{~cm}^{-1}$, and $1029-1022 \mathrm{~cm}^{-1}$ are observed for CST-AAMs, CGTAAMs and SPC AAMs, respectively. The chemical and mineralogical characteristics of CST, CGT and SPC affect the shifts in the spectra and the Si/Al ratio influences the changes observed (46). During the curing time, there is a slight change in the main band, due to the reaction processes. Initially there is a greater release of aluminum species, due to the Al-O bond being weaker than $\mathrm{Si}-\mathrm{O}$, and as the reaction continues more silicon species are available. These processes are reflected on the FTIR spectrum, firstly with a change to the lower region followed by a return to higher wavenumbers (46). No alteration in the FTIR spectra was noted with the addition of $\mathrm{OPC}$, since the calcium content is low. Pyrite minerals are associated with bands lower than $500 \mathrm{~cm}^{-1}$ (48), since sulfur is heavier than oxygen, and the frequencies of cation-anion vibrations occur in regions of low energy (49). In Figure 12, vibration bands can be observed at $418-420 \mathrm{~cm}^{-1}$, which could indicate $\mathrm{S}-\mathrm{S}$ bonds.

SEM/EDS analysis of 100CST, 100CGT, 100 SPC and 75SPC25OPC was performed to identify the reaction products and their morphology. Figure 14 shows the main images selected. The EDS was carried out at 2 to 6 points for each compound. 
(a)
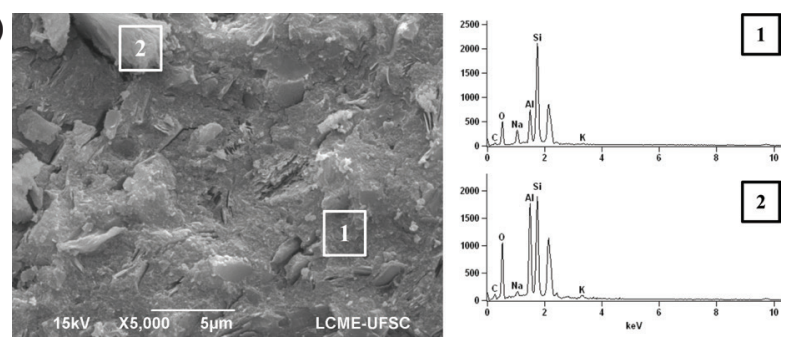

(c)
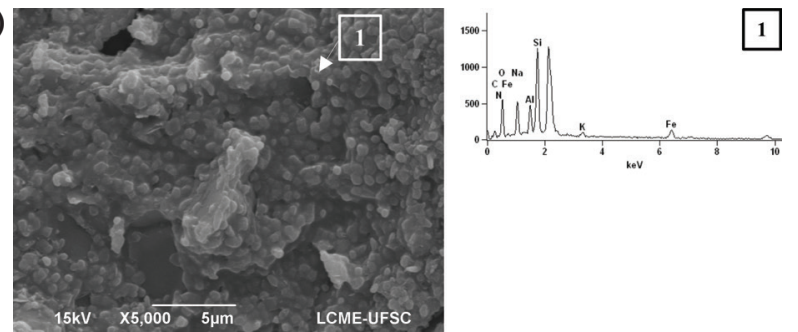

(e)
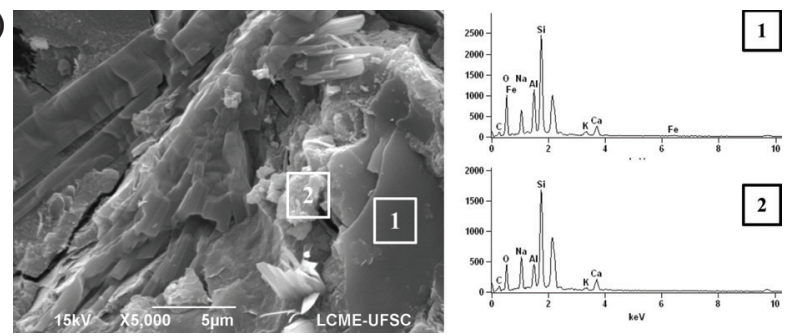

(b)
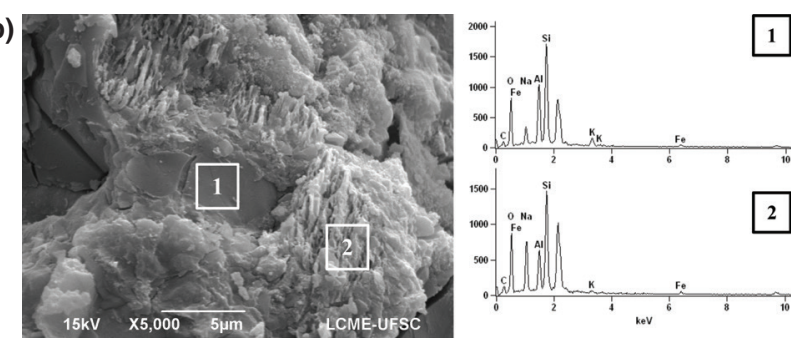

(d)
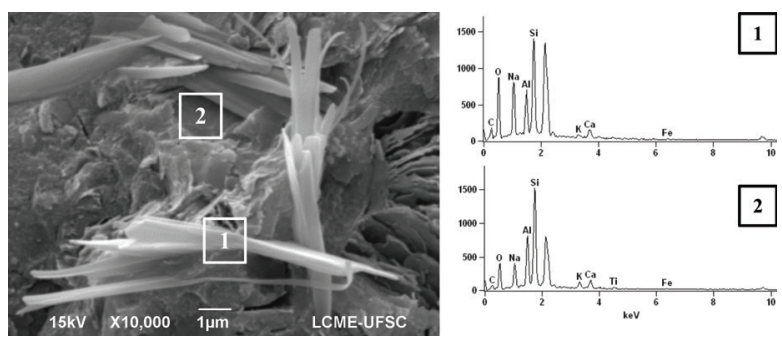

FIGURE 14. SEM images and EDS results for the paste samples of AAM at 28 days: (a) 100CST $(\times 5000)$

(b) 100CGT $(\times 5000)$; (c) 100SPC $(\times 5000)$; (d) 75CST25OPC $(\times 10000)$; and (e) 75CST25OPC $(\times 5000)$.

The main chemical elements are $\mathrm{Si}, \mathrm{Al}$ and $\mathrm{Na}$ along with traces of $\mathrm{Ca}$ and $\mathrm{Fe}$, suggesting the formation of $\mathrm{N}-\mathrm{A}-\mathrm{S}-\mathrm{H}$ gels. The $\mathrm{Si} / \mathrm{Al}$ ratio ranges from 1.5 to 6.8 and $\mathrm{Na} / \mathrm{Al}$ from 0.10 to 7.0 , depending on the compound. The 100CST sample (Figure 14a) showed the lowest ratios and a more homogeneous and dense matrix compared with the other samples analyzed. The presence of the Fe ion was identified, notably in the case of 100CGT (Figure 14b), with an Fe/Si ratio of around 0.10 . According to Djobo et al. (50), during alkali activation the aluminum ion can be replaced by iron. The incorporation of iron can be attributed to its presence in the vitreous form in the precursors. Davidovits et al. (51) report the possibility of iron-containing ferro-siliates structures (-Fe-O-Si-O-Al-O-).

The 100SPC sample (Figure 14c) showed a heterogeneous matrix and some circular forms, which suggests the initiation of the nucleation of the gels, but not polymerization. Based on this observation, some particles may have reacted (50), producing a less dense and resistant matrix. Needle-shaped morphologies are seen for 75CST25OPC (Figure 14d), containing $\mathrm{Na}, \mathrm{Al}, \mathrm{Si}$ and traces of $\mathrm{Ca}$. The mean $\mathrm{Ca} / \mathrm{Si}$ ratio for this system is 0.15 , suggesting the incorporation of calcium into the matrix and the formation of N-(C)-A-S-H. Figure 14e shows plateshaped forms $(13,50)$, in which iron ions are present.

A ternary phase diagram (Figure 15) was produced for the chemical compositions of the precursor materials. This model was suggested by Ismail et al. (47) for FA-GGBS alkali-activated cement, considering the $\mathrm{Al}, \mathrm{Si}$ and $\mathrm{Ca}$ contents. The right side of the graph shows the AAMs with the formation of N-A-S-H. The upper part contains the silica-rich $(>70 \% \mathrm{Si})$ materials, which have the lowest values for mechanical performance. The Al-rich (30-40\% Al) materials in the lower part, which have better mechanical performance, are those produced with CST and metakaolin addition. Towards the left side of the graph are the materials with the addition of Portland cement, which increases the $\mathrm{Ca} / \mathrm{Si}$ ratio from zero to 0.15 (approximately). Materials containing in the region of $5-20 \% \mathrm{Ca}$ tend to incorporate this ion, forming the $\mathrm{N}-(\mathrm{C})-\mathrm{A}-\mathrm{S}-\mathrm{H}$, as evidenced by the SEM.

\subsection{Mortar characteristics}

The dynamic Young's Modulus (Ed) values were obtained at 7, 14, 21 and 28 days, and on the last day the samples were submitted to compressive strength 


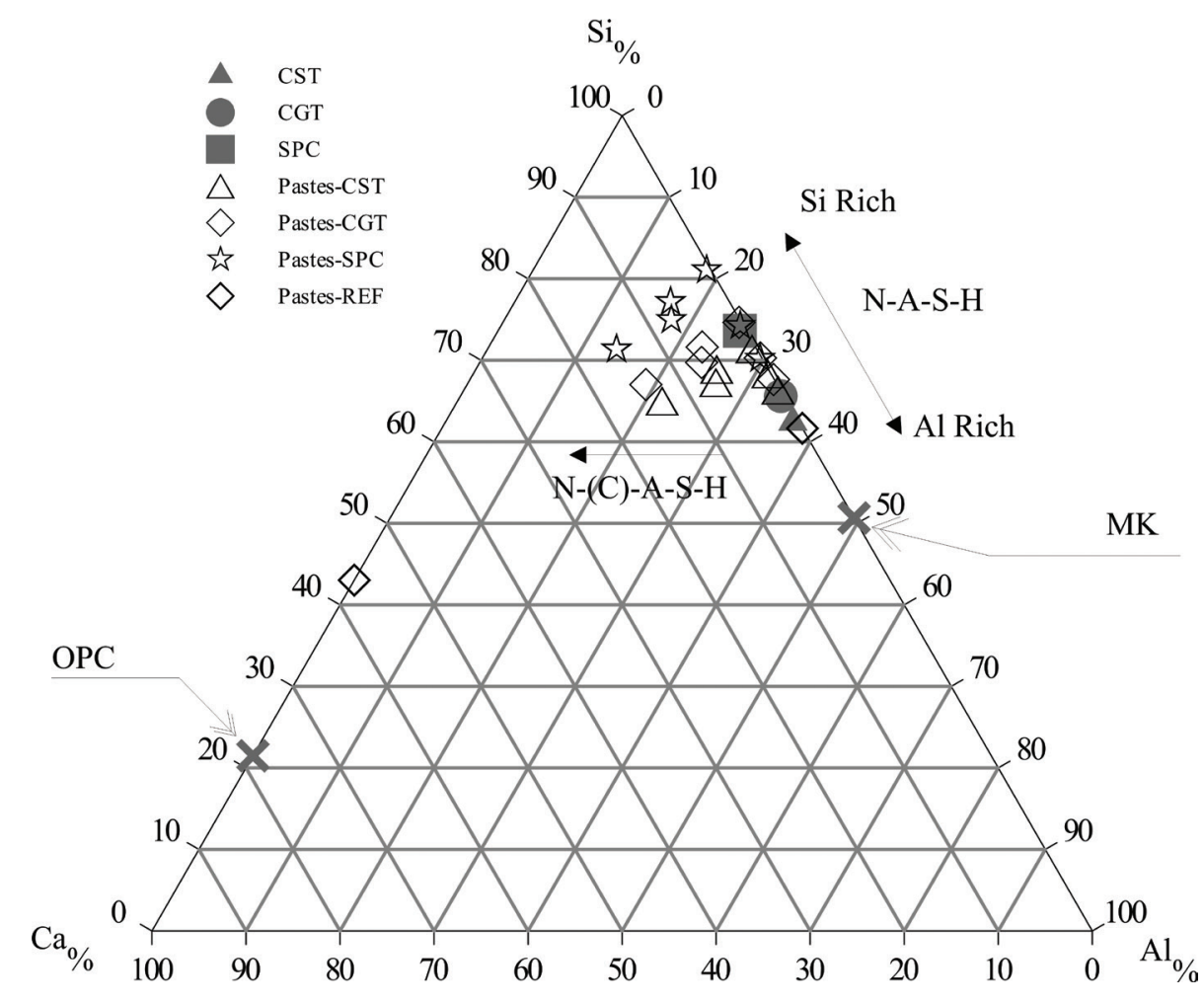

Figure 15. Ternary phase diagram obtained from the $\mathrm{Si}, \mathrm{Al}$ and $\mathrm{Ca}$ content.

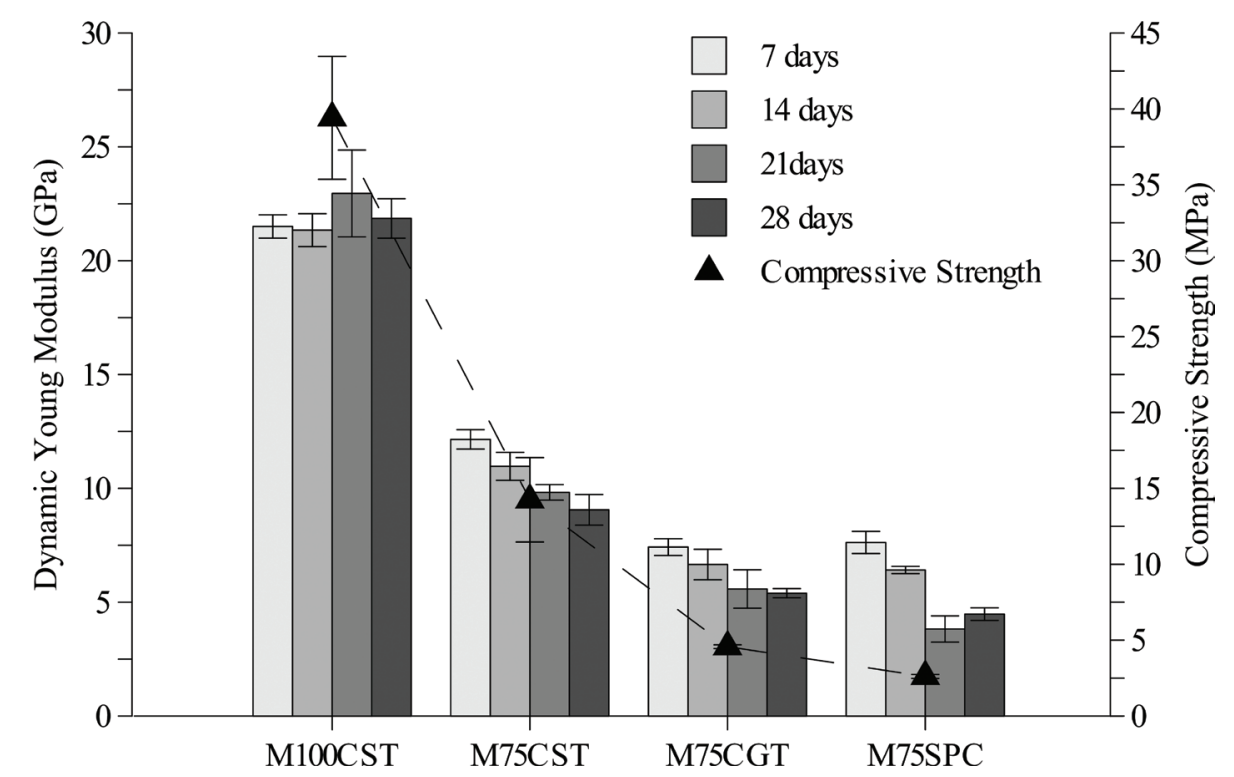

FIGURE 16. Dynamic Young's modulus and compressive strength results (at 7,14, 21 and 28 days).

(fc) tests. Figure 16 shows the results obtained. The M100CST presented higher values than the other mortars. The compressive strength values were $39.4 \mathrm{MPa}, 14.2 \mathrm{MPa}, 4.6 \mathrm{MPa}$ and $2.6 \mathrm{MPa}$ for M100CST, M75CST, M75CGT and M75SPC, respectively. Mortars with Portland cement added needed extra water, which adversely affected the mechanical performance. The chemical characteristics of the waste may have influenced the mechanical properties. For the hybrid mortars, the Ed value 
decreased during the curing time and the M75CGT and M75SPC specimens showed degradation. The Ed values were 21.9 GPA, 9.1 GPA, 5.4 GPA and 4.5 GPA for M100CST, M75CST, M75CGT and M75SPC, respectively.

The ultrasonic pulse velocity (UPV) is inversely related to the time a stress wave travels through a solid. Cracks, voids, density and water content are factors that can affect the UPV. Table 3 shows the results for the specimens at 7, 14, 21 and 28 days. M100CST shows a slight increase in the UPV (2.5\%) over the test ages, but the M75CST, M75CGT and M75SPC present reductions of $12.1 \%, 13.9 \%$ and $22.4 \%$, respectively. These results indicate the quality of the mortars, as the appearance of cracks, voids and a poorly developed microstructure may lead to a reduction in the UPV. The bulk density is similar for all mortars, but the open porosity and water absorption show differences $(<10 \%$ for M100CST and $>20 \%$ for the others). The UPV is directly related to the compressive strength and the compactness of the samples (52). Figure 17 shows the correlations between the UPV and the compressive strength, water absorption (w.a.) and sorptivity (S). The higher the UPV, the higher the compressive strength and the lower the water absorption and sorptivity will be.

The degradation in M75CGT and M75SPC mortars may be related to the mineralogical composition. One hypothesis in this regard is the reaction of sulfide minerals, such as pyrite, which can lead to degradation of the material. However, durability tests would need to be performed to verify this behavior.

Capillary water absorption is shown in Figure 18 and the hybrid mortars have higher absorption and lower saturation time. M75CGT and M75SPC have saturation times of less than $2 \mathrm{~h}$ whereas for M75CST and M100CST the saturation times are $6 \mathrm{~h}$ and $24 \mathrm{~h}$, respectively. This behavior is related to the high open porosity presented by the hybrid mortars $(>20 \%)$. The mechanical and physical characteristics can be related, as shown in Figure 19.
The mortars with higher sorptivity have higher porosity and lower mechanical resistance.

The development of microstructures and the appearance of cracks may be the main factors affecting the mechanical and physical performance. Visual surface detachment was observed for M75CGT and M75SPC, in agreement with the results obtained, mainly for the UPV, suggesting the appearance of cracks and degradation of the specimens.

The high porosity may be related to the low compressive strength (53). Hasselman (54) suggested a linear correlation between these properties for refractory materials, as presented in Eq. [3] (55), where $\sigma_{0}$ is the strength at zero porosity, $\mathrm{c}$ is an empirical constant and $\mathrm{p}$ is porosity.

$$
\sigma=\sigma_{0+} c p
$$

Figure 20 shows the correlations obtained. The resulting equations are $\sigma=-2.91 \mathrm{p}+67.50\left(\mathrm{r}^{2}=0.88\right)$ and $\mathrm{E}=-1.40 \mathrm{p}+35.41\left(\mathrm{r}^{2}=0.93\right)$ for the compressive strength and modulus of elasticity, respectively. These equations could aid the prediction of the mechanical characteristics of the mortars studied. Figure 21 shows the mass variation (MV) over time. Although the MV is similar for all mortars at 28 days, the mechanisms involved may differ in each case. The main factor influencing the MV is the loss of free water, but for M75SPC and M75CGT the degradation of the specimens may also play a role, as seen from the UPV analysis. In the case of M100CST, the variation may be related to the formation of the reaction gels (25), since these presented low porosity and a higher UPV.

\section{DISCUSSION}

Previous studies on coal mining waste have demonstrated the potential for its use in alkali-activated material since it is rich in silicon and aluminum $(6-8)$. However, pre-treatment processes are required $(6,9)$. The aim of this research was to evaluate the

TABLE 3. Results for the mechanical properties of the mortars

\begin{tabular}{|c|c|c|c|c|c|c|c|c|c|c|}
\hline \multirow{3}{*}{$\begin{array}{l}\text { Mixes } \\
\text { M100CST }\end{array}$} & \multicolumn{4}{|c|}{ UPV km/s } & $\begin{array}{c}f_{2} c_{28} \\
\text { (MPa) }\end{array}$ & $\begin{array}{c}\text { Ed } \\
(\mathbf{G P a})\end{array}$ & w.a. $(\%)$ & P. $(\%)$ & $\begin{array}{l}\text { Bulk Density } \\
\left(\mathrm{g} / \mathrm{cm}^{3}\right)\end{array}$ & $\mathrm{S}\left(\mathrm{m} . \mathrm{s}^{1 / 2}\right)$ \\
\hline & $7 \mathrm{~d}$ & $14 \mathrm{~d}$ & 21d & $28 \mathrm{~d}$ & \multicolumn{6}{|c|}{$28 \mathrm{~d}$} \\
\hline & $\begin{array}{c}3.27 \\
(0.04)\end{array}$ & $\begin{array}{c}3.28 \\
(0.06)\end{array}$ & $\begin{array}{c}3.41 \\
(0.14)\end{array}$ & $\begin{array}{c}3.34 \\
(0.07)\end{array}$ & $\begin{array}{l}39.4 \\
(4.0)\end{array}$ & $\begin{array}{l}21.9 \\
(0.9)\end{array}$ & $\begin{array}{c}4.83 \\
(0.13)\end{array}$ & $\begin{array}{l}9.77 \\
(0.26)\end{array}$ & $2.24(0.01)$ & 0.0056 (first 24h) \\
\hline $\mathrm{M} 75 \mathrm{CST}$ & $\begin{array}{c}2.54 \\
(0.04)\end{array}$ & $\begin{array}{c}2.42 \\
(0.07)\end{array}$ & $\begin{array}{c}2.29 \\
(0.04)\end{array}$ & $\begin{array}{c}2.23 \\
(0.08)\end{array}$ & $\begin{array}{l}14.2 \\
(2.8)\end{array}$ & $\begin{array}{l}9.1 \\
(0.7)\end{array}$ & $\begin{array}{l}11.16 \\
(0.82)\end{array}$ & $\begin{array}{l}20.52 \\
(0.12)\end{array}$ & $2.32(0.02)$ & 0.0101 (first 6.8h) \\
\hline M75CGT & $\begin{array}{l}1.99 \\
(0.05)\end{array}$ & $\begin{array}{l}1.88 \\
(0.09)\end{array}$ & $\begin{array}{l}1.73 \\
(0.13)\end{array}$ & $\begin{array}{l}1.71 \\
(0.03)\end{array}$ & $\begin{array}{c}4.6 \\
(0.1)\end{array}$ & $\begin{array}{c}5.4 \\
(0.2)\end{array}$ & $\begin{array}{l}11.54 \\
(0.15)\end{array}$ & $\begin{array}{l}20.50 \\
(0.17)\end{array}$ & $2.23(0.03)$ & 0.0135 (first $2.4 \mathrm{~h}$ ) \\
\hline M75SPC & $\begin{array}{l}2.01 \\
(0.06)\end{array}$ & $\begin{array}{l}1.86 \\
(0.02)\end{array}$ & $\begin{array}{c}1.44 \\
(0.01)\end{array}$ & $\begin{array}{l}1.56 \\
(0.05)\end{array}$ & $\begin{array}{l}2.6 \\
(0.1)\end{array}$ & $\begin{array}{c}4.5 \\
(0.3)\end{array}$ & $\begin{array}{l}12.36 \\
(0.23)\end{array}$ & $\begin{array}{l}21.16 \\
(0.49)\end{array}$ & $2.17(0.02)$ & 0.0153 (first $1.6 \mathrm{~h}$ ) \\
\hline
\end{tabular}

Average: $\mathrm{N}=3$ / (standard deviation) / w.a. is water absorption / $\mathrm{P}$ is open porosity. 
(a)

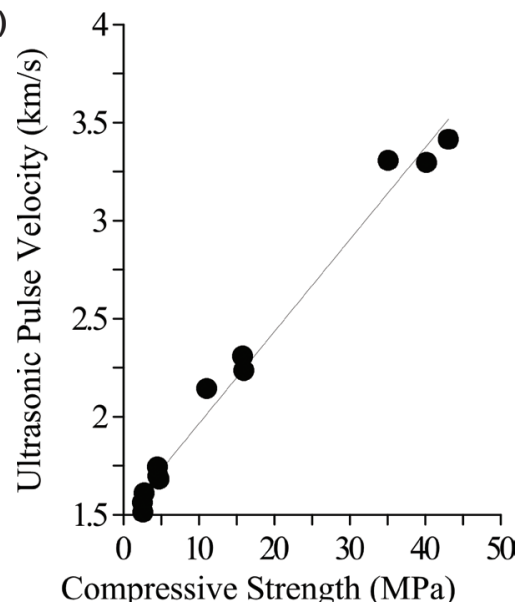

$f(x)=46.7 x+1513.3\left(r^{2}=0.99\right)$ (b)

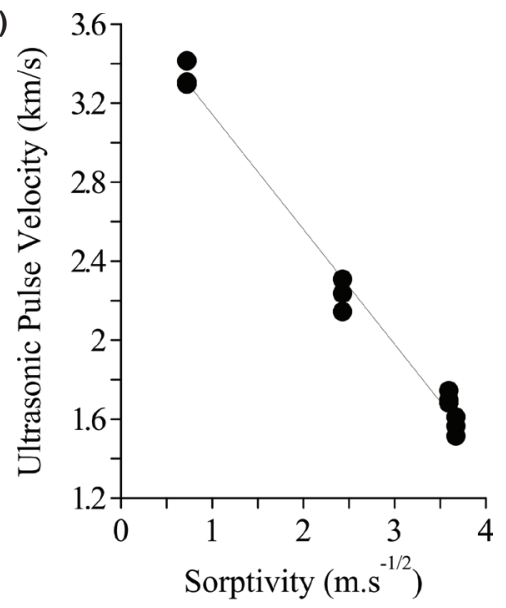

$f(x)=-577.6 x+3727.5\left(r^{2}=0.98\right)$ (c)

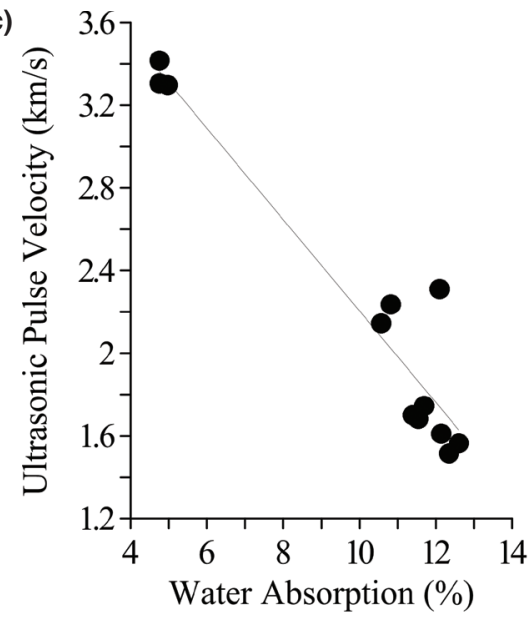

$f(x)=-220.1 x+4418.7\left(r^{2}=0.92\right)$

FIGURE 17. Correlation between ultrasonic pulse velocity and (a) compressive strength, (b) sorptivity and (c) water absorption, and their curve fitting.

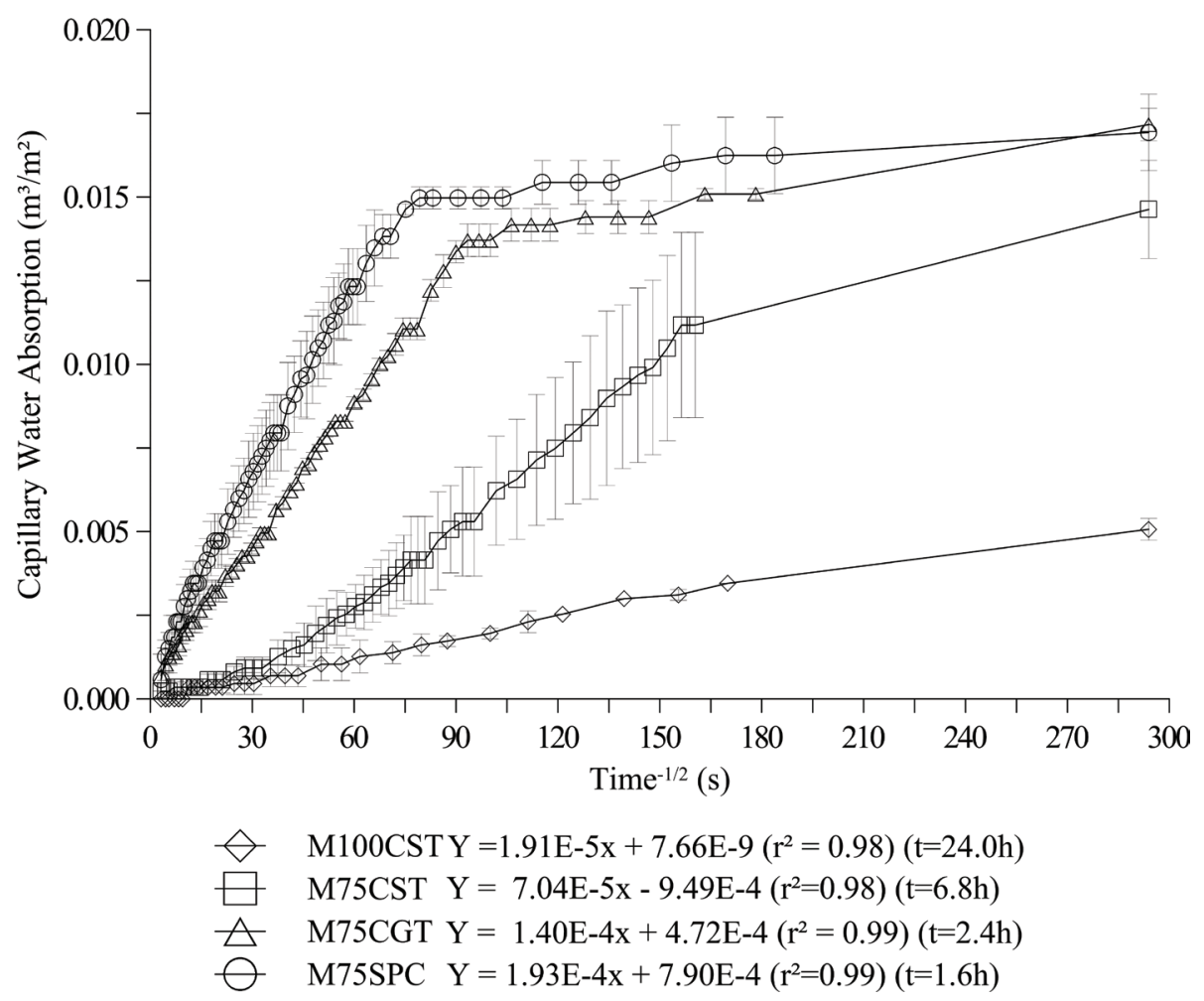

FIGURE 18. Evolution of capillary water absorption of the mortars versus $\sqrt{ } \mathrm{t}$.

influence of three different wastes on the mechanical performance and microstructural development of AAM, since the chemical, physical and mineralogical characteristics play an important role in this regard (44).

The different coal mining wastes showed variations in the $\mathrm{Si} / \mathrm{Al}$ ratio, particle size (smallest for CST) and
$\mathrm{Si}+\mathrm{Al}$ concentration $(>70 \%)$. A calcination process is necessary to improve the content of amorphous silicon and aluminum, due to the dehydroxylation of kaolinite. The peaks associated with kaolinite disappear after calcination, as observed in the XRD results (Figure 2) for CST and CGT. The SPC undergoes natural combustion and was not calcined. All samples 


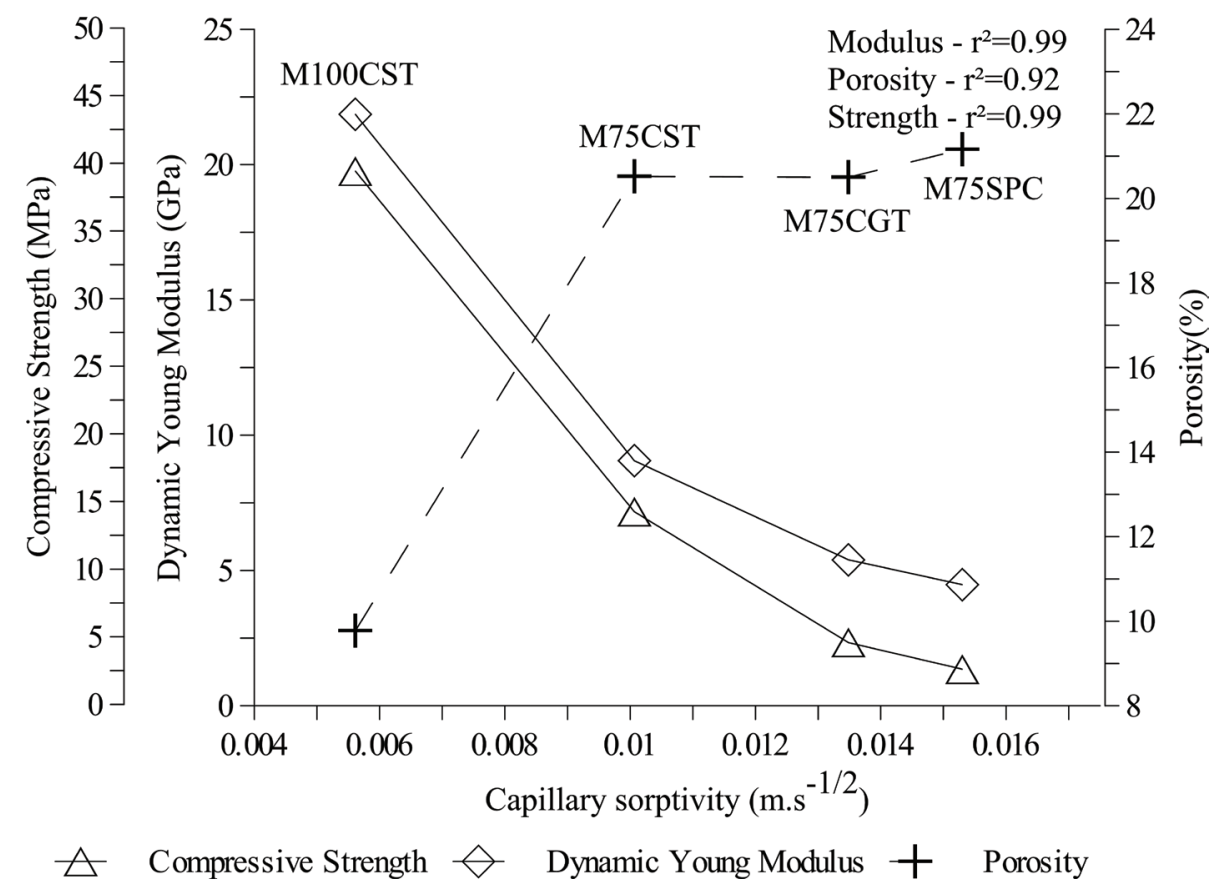

FIGURE 19. Capillary sorptivity versus mechanical properties of the mortars.

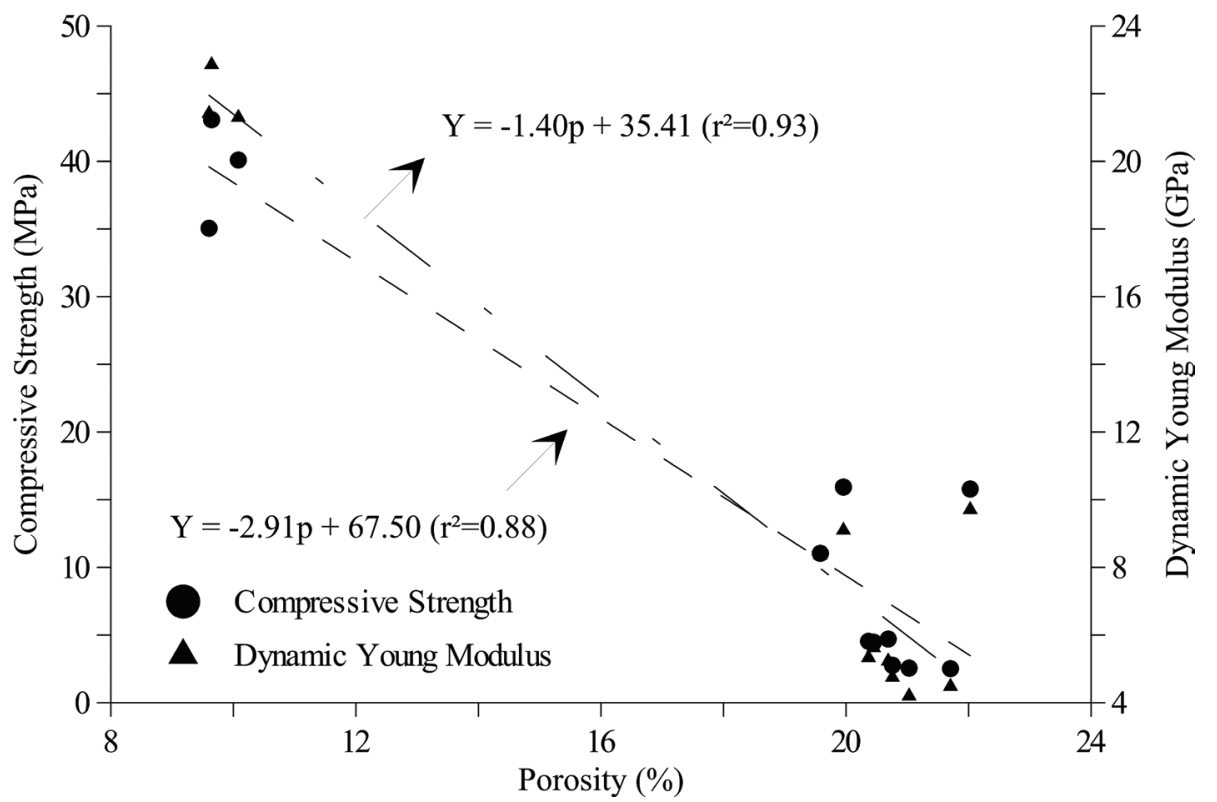

FIGURE 20. Correlation of compressive strength and dynamic modulus of elasticity with porosity, using the linear regression model proposed by Hasselmann (55).

show crystalline peaks, for instance, those related to quartz and muscovite.

The results show that the mechanical performance is affected by the waste characteristics. The CST-AAM has higher compressive strength than CGT-AAM and SPPC-AAM and the latter showed the poorest performance (Figure 5). The compressive strength of 100CST is more than $30 \mathrm{MPa}$ at day
1 and reaches $69 \mathrm{MPa}$ at day 28 (Figure 3). The MK addition did not change the results significantly. However, with the addition of OPC the compressive strength (Figure 4) was low at day 1 for 100CGT but reached $25 \mathrm{MPa}$ at day 28.

The addition of metakaolin increased the content of silicon and aluminum available for reaction and reduced the Si/Al ratio. The compressive 


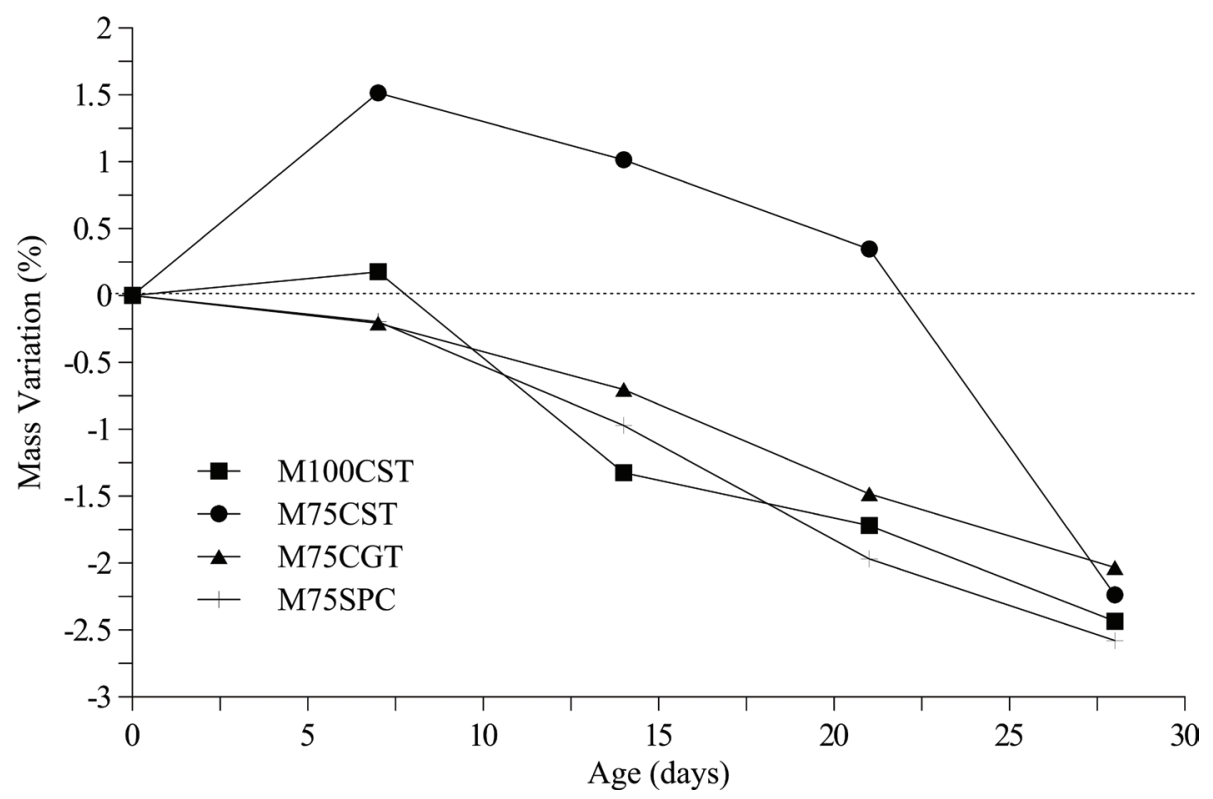

Figure 21. Mass variation during reaction period (average of 6 samples).

strength at day 1 was $90 \%$ of the total for $100 \mathrm{MK}$. For the CGT-MK blend there was an increase in the early strength, however for SPC-MK only $50 \%$ of MK increased the compressive strength.

With the addition of Portland cement there was an increase in the $\mathrm{CaO}$ content and the $\mathrm{Ca} / \mathrm{Si}$ ratio (from zero to 0.15 ), and thus in the reactive silicon content. There was a rapid loss of workability due to the fast alkaline reaction, even with a small amount of OPC added. An increase in the compressive strength and stiffness was evidenced for CGT-OPC at an early age.

The results of the microstructural analysis showed the presence of N-A-S-H gel while in the XRD analysis the formation of a halo was observed between $20-25^{\circ}$ ( $2 \theta$ value) (45). The higher peak intensity for 100CST compared with 100CGT and 100SPC can be attributed to the properties of the raw materials, which influence the mechanical performance. In the FTIR results, the highest peak intensity was observed in the region of $800-1200 \mathrm{~cm}^{-1}$ for the $100 \mathrm{CST}$. This band is characterized by the asymmetric vibration of Si-O-T $(45,46)$, and its change is related to the reaction mechanisms. The results show that the mechanical performance is related to microstructural development. The SEM analysis (Figure 14b) showed iron ions incorporated into the reaction gels. Peaks associated with pyrite (Figure 2) and Fe content are present in the case of CGT. The XRD results for CGT-AAM show that the peak for pyrite remains after the alkali-activation (Figure 9), suggesting the immobilization of this mineral. Pyrite oxidizes easily in the presence of moisture, causing acid drainage from mines and the leaching of heavy metals $(3,4)$. The potential for pyrite immobilization in cement matrixes could offer a solution to address this environmental problem.

The second stage of this research involved an evaluation of the physical and mechanical performance of the mortars. The results showed high mechanical strength for M100CST (39.4 MPa), low porosity $(<10 \%)$ and low sorptivity. However, the M75CGT and M75SPC specimens showed a reduction in the UPV over time, which indicates a deterioration of the mortars, due to the appearance of cracks and voids. The UPV is directly related to the porosity, compressive strength and sorptivity (Figure 17). This research study demonstrates that the different characteristics of the residues influence the mechanical and microstructural performance of AAMs and that CST and CGT residues have the greatest potential for use in these systems.

\section{CONCLUSIONS}

Coal gangue was used as a binder in AAM systems and the main conclusions that can be drawn from this study are:

- Pre-treatment employing grinding and calcination can increase the coal gangue reactivity;

- The CST mixes presented the best performance in both pastes and mortars. This could be related to the higher amount of amorphous or vitreous phase as main component of the raw material, which can improve the reaction during polymerization; 
- The coarse gangue could be alkali-activated, most notably in the MK cement. In this system, a decrease in the $\mathrm{Si} / \mathrm{Al}$ ratio $(\mathrm{mol} / \mathrm{mol})$ occurred, promoting a better mechanical performance. The addition of OPC led to an increase in the $\mathrm{Ca} / \mathrm{Si}$ ratio and N-(C)-A-S-H gel formation;

- The CGT-AAM showed the potential for pyrite immobilization, which is important for addressing environmental issues;

- The SPC-AAM presented poor performance in terms of both reactivity and strength. UPV measurements allowed the detection of a poorlyformed matrix; and

- The main gel formed was N-A-S-H, with points of Fe bonding. The higher incidence of this gel led to better mechanical performance.

\section{ACKNOWLEDGMENTS}

The authors would like to acknowledge the financial support from the CAPES and CNPq. We are also grateful to LMCE for help with the SEM analysis.

\section{REFERENCES}

1. https://www.iea.org

2. https://www.worldcoal.org

3. Simate, G. S.; Ndlovu, S. (2014) Acid mine drainage: challenges and opportunities. J. Environ. Chem. Eng. 2 [3], 1785-1803. https://doi.org/10.1016/j.jece.2014.07.021.

4. Kefeni, K. K.; Msagati, T.A.M.; Mamba, B.B. (2017) Acid mine drainage: prevention, treatment options, and resource recovery. J. Clean. Prod. 151, 475-493. https://doi. org/10.1016/j.jclepro.2017.03.082.

5. Querol, X.; Izquierdo, M.; Monfort, E.; Alvarez, E.; Font, O.; Moreno, T.; Alastuey, A.; Zhuang, X.; Lu, W.; Wang, Y. (2008) Environmental characterization of burnt coal gangue banks at Yangquan, Shanxi Province, China. Int. J. Coal. Geol. 75 [2], 93-104. https://doi.org/10.1016/j. coal.2008.04.003

6. Gong, C.; Li, D.; Wang, X.; Li, Z. (2007) Activity and structure of calcined coal gangue. J. Wuhan University of Technol-mater. 22 [4], 749-753. https://doi.org/10.1007/ s11595-006-4749-8.

7. Cao, Z.; Cao, Y.; Dong, H.; Zhang, J.; Sun, C. (2016) Effect of calcination condition on the microstructure and pozzolanic activity of calcined coal gangue. Int. Miner. Process. 146, 23-28. https://doi.org/10.1016/j.minpro.2015.11.008.

8. Cutruneo, C. M. N. L.; Oliveira, M. L.S.; Ward, C. R.; Hower, J. C.; de Brum, I. A.S.; Sampaio, C. H.; Kautzmann, R. M.; Taffarel, S. R.; Teixeira, E. C.; Silva, L. F. O. (2014) A mineralogical and geochemical study of three Brazilian coal cleaning rejects: Demonstration of electron beam applications. Int. J. Coal Geol. 130, 33-52. https://doi.org/ 10.1016/j.coal.2014.05.009.

9. Cheng, Y.; Hongqiang, M.; Hongyu, C.; Jiaxin, W.; Jing, S.; Zonghui, L.; Mingkai, Y. (2018) Preparation and characterization of coal gangue geopolymers. Constr. Build. Mater. 187, 318-326. https://doi.org/10.1016/j.conbuildmat.2018.07.220

10. Frías, M.; La Villa, R. V.; Rojas, M. S.; Medina, C.; Juan Valdés, A. (2012) Scientific aspects of kaolinite based coal mining wastes in Pozzolan/Ca(OH) 2 System. J. Am. Ceram. Soc. 95 [1], 386-391. https://doi.org/10.1111/j.1551-2916. 2011.04985.x.

11. Dong, Z.; Xia, J.; Fan, C.; Cao, J. (2015) Activity of calcined coal gangue fine aggregate and its effect on the mechanical behavior of cement mortar. Constr. Build. Mater. 100, 63-69. https://doi.org/10.1016/j.conbuildmat.2015.09.050.

12. García, R.; Vigil de La Villa, R.; Frías, M.; Rodriguez, O.; Martínez-Ramírez, S.; Fernández-Carrasco, L.; de Soto, I. S.; Villar-Cociña, E. (2015) Mineralogical study of calcined coal waste in a pozzolan $/ \mathrm{Ca}(\mathrm{OH})_{2}$ system. $\mathrm{Appl}$. Clay Sci. 108, 45-54. https://doi.org/10.1016/j.clay.2015. 02.014 .

13. Gao, Y.; Huang, H.; Tang, W.; Liu, X.; Yang, X.; Zhang, J. (2015) Preparation and characterization of a novel porous silicate material from coal gangue. Micropor. Mesopor. Mater. 217, 210-218. https://doi.org/10.1016/j. micromeso.2015.06.033.

14. Frías, M.; Sanchez de Rojas, M. I.; García, R.; Juan Valdés, A.; Medina, C. (2012) Effect of activated coal mining wastes on the properties of blended cement. Cem. Concr. Compos. 34 [5], 678-683. https://doi.org/10.1016/j. cemconcomp.2012.02.006.

15. Li, C.; Wan, J.; Sun, H.; Li, L. (2010) Investigation on the activation of coal gangue by a new compound method. $J$. Hazard Mater. 179 [1-3], 515-520. https://doi.org/10.1016/j. jhazmat.2010.03.033.

16. Taha, Y.; Benzaazoua, M.; Hakkou, R.; Mansori, M. (2017) Coal mine wastes recycling for coal recovery and eco-friendly bricks production. Miner. Eng. 107, 123-138. https://doi.org/10.1016/j.mineng.2016.09.001.

17. Zhou, C.; Liu, G.; Wu, S.; Lam, P. K. S. (2014) The environmental characteristics of usage of coal gangue in bricking-making: a case study at Huainan, China. Chemosphere. 95, 274-280. https://doi.org/10.1016/j.chemosphere.2013. 09.004.

18. Huang, G.; Ji, Y.; Li, J.; Hou, Z.; Dong, Z. (2018) Improving strength of calcinated coal gangue geopolymer mortars via increasing calcium content. Constr. Build. Mater. 166, 760-768. https://doi.org/10.1016/j.conbuildmat.2018.02.005

19. Geng, J.; Zhou, M.; Li, Y.; Chen, Y.; Han, Y.; Wan, S.; Zhou, X.; Hou, H. (2017) Comparison of red mud and coal gangue blended geopolymers synthesized through thermal activation and mechanical grinding preactivation. Constr. Build. Mater. 153, 185-192. https://doi.org/10.1016/j. conbuildmat.2017.07.045.

20. Duan, Y.; Wang, P. (2008) Early hydration of the material of alkali-activated coal gangue. J. Mater. Sci. Eng. 4 [26], 511-515.

21. Shi, C.; Fernández-Jiménez, A.; Palomo, A. (2011) New cements for the 21st century: The pursuit of an alternative to Portland cement. Cem. Concr. Res. 41 [7], 750-763. https:// doi.org/10.1016/j.cemconres.2011.03.016.

22. Khale, D.; Chaudhary, R. (2007) Mechanism of geopolymerization and factors influencing its development: a review. J. Mater. Sci. 42 [3], 729-746. https://doi.org/10.1007/ s10853-006-0401-4.

23. Rovnaník, P. (2010) Effect of curing temperature on the development of hard structure of metakaolin-based geopolymer. Constr. Build. Mater. 24 [7], 1176-1183. https:// doi.org/10.1016/j.conbuildmat.2009.12.023.

24. Aydin, S.; Baradan, B. (2014) Effect of activator type and content on properties of alkali-activated slag mortars. Compos. Part B: Eng. 57, 166-172. https://doi.org/10.1016/j. compositesb.2013.10.001.

25. Samson, G.; Cyr, M.; Gao, X. (2017) Formulation and characterization of blended alkali-activated materials based on flash-calcined metakaolin, fly ash and GGBS. Constr. Build. Mater. 144, 50-64. https://doi.org/10.1016/j. conbuildmat.2017.03.160.

26. Bignozzi, M. C.; Manzi, S.; Lancellotti, I.; Kamseu, E.; Barbieri, L.; Leonelli, C. (2013) Mix-design and characterization of alkali-activated materials based on metakaolin and ladle slag. Appl. Clay Sci. 73, 78-85. https://doi.org/ 10.1016/j.clay.2012.09.015.

27. Cheng, H.; Lin, K-L.; Cui, R.; Hwang, C-L.; Cheng, T-W.; Chang, Y-M. (2015) Effect of solid-to-liquid ratios on the properties of waste catalyst-metakaolin-based geopolymers. Constr. Build. Mater. 88, 74-83. https://doi.org/10.1016/j. conbuildmat.2015.01.005. 
28. Slaty, F.; Khoury, H.; Rahier, H.; Wastiels, J. (2015) Durability of alkali-activated cement produced from kaolinitic clay. Appl. Clay Sci. 104, 229-237. https://doi.org/ 10.1016/j.clay.2014.11.037.

29. Saavedra, W. G. V.; Ângulo, D. E.; de Gutiérrez, R. M. (2016) Fly Ash Slag Geopolymer Concrete: Resistance to Sodium and Magnesium Sulfate Attack. J. Mater. Civ. Eng. 28 [12], 04016148-04016157. https://doi.org/10.1061/ (ASCE)MT.1943-5533.0001618.

30. Džunuzović, N.; Komljenović, M.; Nikolić, V.; Ivanović, T. (2017) External sulfate attack on alkali-activated fly ash-blast furnace slag composite. Constr. Build. Mater. 157, 737-747. https://doi.org/10.1016/j.conbuildmat.2017.09.159.

31. Zhang, J.; Shi, C.; Zhang, Z.; Ou, Z. (2017) Durability of alkali-activated materials in aggressive environments: A review on recent studies. Constr. Build. Mater. 152, 598-613. https://doi.org/10.1016/j.conbuildmat.2017.07.027.

32. Komnitsas, K.; Zaharaki, D. (2007) Geopolymerisation: A review and prospects for the minerals industry. Miner. Eng. 20 [14], 1261-1277. https://doi.org/10.1016/j.mineng. 2007.07.011.

33. Fernández-Jiménez, A.; Palomo, A. (2005) Composition and microstructure of alkali-activated fly ash binder: Effect of the activator. Cem. Concr. Res. 35 [10], 1984-1992. https:// doi.org/10.1016/j.cemconres.2005.03.003.

34. Ruiz-Santaquiteria, C.; Skibsted, J.; Fernández-Jiménez, A.; Palomo, A. (2012) Alkaline solution/binder ratio as a determining factor in the alkaline activation of aluminosilicates. Cem. Concr. Res. 42 [9], 1242-1251. https://doi.org/ 10.1016/j.cemconres.2012.05.019.

35. Granizo, N.; Palomo, A.; Fernandez-Jiménez, A. (2014) Effect of temperature and alkaline concentration on metakaolin leaching kinetics. Ceram. Int. 40 [7], 8975-8985. https://doi.org/10.1016/j.ceramint.2014.02.071.

36. ABNT NBR 16697: 2018, Portland cement. Requirements

37. ABNT NBR 8522: 2017, Concrete. Determination of static modulus of elasticity and deformation by compression.

38. Criado, M.; Fernández-Jiménez, A.; Palomo, A. (2007) Alkali activation of fly ash: Effect of the $\mathrm{SiO}_{2} / \mathrm{Na}_{2} \mathrm{O}$ ratio. Micropor. Mesopor. Mater. 106 [1-3], 180-191. https://doi. org/10.1016/j.micromeso.2007.02.055.

39. ABNT NBR 7214: 2015, Standard sand for cement tests. Specification.

40. ABNT NBR 15630: 2009, Mortars applied on walls and ceilings. Determination of elasticity modulus by the ultrasonic wave propagation

41. Santos, F. I. G.; Rocha, J. C.; Cheriaf, M. (2007) Influence of bottom ash replaced natural aggregate and air-entraining agent in moisture transfer mechanisms in mortars. Revista Matéria. 12 [2], 253-268. http://dx.doi.org/10.1590/ S1517-70762007000200003.

42. ABNT NBR 9778: 2009, Hardened mortar and concrete. Determination of absorption, voids and specific gravity.

43. Dimas, D.; Giannopoulou, I.; Panias, D. (2009) Polymerization in sodium silicate solutions: a fundamental process in geopolymerization technology. J. Mater.
Sci. 44 [14], 3719-3730. https://doi.org/10.1007/s10853009-3497-5.

44. Hoyos-Montilla, A.A.; Arias-Jaramillo, Y.P.; Tobón, J.I (2018) Evaluation of cements obtained by alkali-activated coal ash with $\mathrm{NaOH}$ cured at low temperatures. Mater. Construcc. 68 (332), 170, 2018. https://doi.org/10.3989/ mc.2018.10117.

45. Fernández-Jiménez, A.; Palomo, A.; Vazquez, T.; Vallepu, R.; Terai, T.; Ikeda, K. (2008) Alkaline activation of blends of metakaolin and calcium aluminate. J. Am. Ceram. Soc. 91 [4], 1231-1236. https://doi.org/ 10.1111/j.1551-2916.2007.02002.x.

46. Fernández-Jiménez, A.; Palomo, A. (2005) Mid-infrared spectroscopic studies of alkali-activated fly ash structure. Microp. Mesop. Mater. 83, 207-214. https://doi.org/ 10.1016/j.micromeso.2005.05.057.

47. Ismail, I.; Bernal, S. A.; Provis, J. L.; San Nicolas, R.; Hamdan, S.; Van Deventer, J. S. J. (2014) Modification of phase evolution in alkali-activated blast furnace slag by the incorporation of fly ash. Cem. Concr. Compos. 45, 125-135. https://doi.org/10.1016/j.cemconcomp.2013.09.006.

48. Reyes-Bozo, L.; Escudey, M.; Vyhmeister, E.; Higueras, P.; Godoy-Faúndez, A.; Salazar, J. L.; Valdés-González, H.; Wolf-Sepúlveda, G.; Herrera-Urbina, R. (2015) Adsorption of biosolids and their main components on chalcopyrite, molybdenite and pyrite: Zeta potential and FTIR spectroscopy studies. Miner. Eng. 78, 128-135. https://doi. org/10.1016/j.mineng.2015.04.021.

49. White, W. B.; Roy, R. (1964) Infrared spectra-crystal structure correlations: ii. Comparison of simple polymorphic minerals. The Am. Mineral. 49 [11-12], 1670-1687.

50. Yankwa Djobo, J. N.; Elimbi, A.; Tchakout, H. K.; Kumar, S. (2016) Mechanical activation of volcanic ash for geopolymer synthesis: effect on reaction kinetics, gel characteristics, physical and mechanical properties. Res. Adv. 6 [45], 39106-39117. https://doi.org/10.1039/c6ra03667h.

51. Davidovits, F.; Davidovits, J.; Davidovits, M. (2013) Geopolymer Cement of The Calcium Ferro-Aluminosilicate Polymer Type And Production Process EP 2632870 A1.

52. Wang, C.C.; Wang, H.Y.; Chen, B.T.; Peng, Y.C. (2017) Study on the engineering properties and prediction models of an alkali-activated mortar material containing recycled waste glass. Constr. Build. Mater. 132, 130-141. https://doi. org/10.1016/j.conbuildmat.2016.11.103.

53. Mangat, P. S.; Ojedokun, O. O. (2018) Influence of curing on pore properties and strength of alkali activated mortars. Constr. Build. Mater. 188, 337-348. https://doi. org/10.1016/j.conbuildmat.2018.07.180.

54. Hasselman, D. P. H. (1969) Griffith flaws and the effect of porosity on tensile strength of brittle ceramics. J. Am. Ceram. Soc. 52,457.https://doi.org/10.1111/j.1151-2916.1969. tb11982.x.

55. Chen, X.; Wu, S.; Zhou, J. (2013) Influence of porosity on compressive and tensile strength of cement mortar. Constr. Build. Mater. 40, 869-874. https://doi.org/10.1016/j. conbuildmat.2012.11.072. 